\title{
A perched, high-elevation wetland complex in the Atacama Desert (northern Chile) and its implications for past human settlement
}

Luca Sitzia $^{\mathrm{a}, \mathrm{b}}$, Eugenia M. Gayo ${ }^{\mathrm{c}}$, Marcela Sepulveda ${ }^{\mathrm{d}, \mathrm{e}}$, Juan S. González , Lucia Ibañez $^{\mathrm{g}}$, Alain Queffelec $^{\text {h }}$, Ricardo De Pol-Holz ${ }^{\mathrm{i}}$

${ }^{a}$ Universidad de Tarapacá, Facultad de Ciencias Sociales y Jurídicas, Arica, 1000000, Chile

${ }^{b}$ Laboratorio de Análisis e Investigaciones Arqueométricas, Museo Universidad de Tarapacá San Miguel de Azapa XV, Región de Arica y Parinacota, Camino a Azapa Km 12, Arica, 1000000, Chile

${ }^{\mathrm{c}}$ Center for Climate and Resilience Research and Departamento de Oceanografía, Facultad de Ciencias Naturales y Oceanográficas, Universidad de Concepción, Concepción, 4030000, Chile

${ }^{d}$ Laboratorio de Análisis e Investigaciones Arqueométricas, Instituto de Alta Investigación, Universidad de

Tarapacá, Antofagasta 1520, Casilla 6-D, Arica, 1000236, Chile

eUnité Mixte de Recherche 8096 Archéologie des Amériques (Centre National de la Recherche Scientifique Université Paris 1), France

IIndependent researcher

gFacultad de Ciencias Naturales e Instituto Miguel Lillo, Universidad Nacional de Tucumán, Miguel Lillo 205, 4000, Tucumán, Argentina

hPACEA (De la Préhistoire à l'Actuel : Culture, Environnement et Anthropologie), Unité mixte de recherche 5199, Centre National de la Recherche Scientifique, Université de Bordeaux, bâtiment B18, Allée Geoffroy Saint-Hilaire, 33615 Pessac Cedex, France

${ }^{\mathrm{i}}$ Center for Climate and Resilience Research and GAIA-Antarctica, Universidad de Magallanes, Punta Arenas, 6200000, Chile

\section{Abstract}

A previously undocumented type of wetland is described from the Atacama Desert in northern Chile (3000 $\mathrm{m}$ above sea level), sustained exclusively by direct precipitation and perched above the regional water table. Geomorphological mapping, pedostratigraphy, geochemistry, and analysis of contemporary vegetation is used to understand wetland formation and dynamics during historical and present time periods. The paleowetland deposits overlie a Miocene tuff that acts as an impermeable barrier to water transfer and creates conditions for local shallow ground water. These deposits include several paleosols that were formed during periods when precipitation increased regionally at 7755-7300, 1270, 545, and 400-300 cal yr BP. The similarity in timing with other palaeohydrological records for the Atacama implies that paleosols from this wetland are proxies for reconstructing past changes in local and regional hydrological cycle. Archaeological investigations have revealed the presence of two small farms from the Late Intermediate period, i.e., during the earliest wetter phase represented by the paleosols. Both farms are located near the paleowetland deposits, which suggests that local inhabitants exploited these water sources during late pre-Hispanic times. Results of this study improve knowledge of settlement patterns during this and earlier cultural periods.

Keywords: Holocene; Central Andes; Atacama Desert; Tuff; Volcanic ash; Desert wetlands; Perched wetlands; Late Intermediate period 


\section{INTRODUCTION}

Wetlands have sustained human activities since prehistoric times, including freshwater provisioning, vegetation cover, fauna resources, waterlogged soils, and nutrient and sediment recycling (e.g., Aber et al., 2012). From the perspective of Quaternary geology, paleowetland deposits constitute key geohistorical archives, widely used to reconstruct past fluctuations in the global hydrological cycle (e.g., Alley et al., 2002; Junk et al., 2013; Pigati et al., 2014), forcing mechanisms for glacial-interglacial cycles (Vandergoes et al., 2005), and historical anthropogenic pollution (Bindler, 2006; Vleeschouwer et al., 2014). This particularly applies to arid regions, where paleoenvironmental proxy records are limited. Although considerable progress has been made in defining physical, sedimentological, and biological features of ground-water discharge deposits (GWD; e.g., Tooth and McCarty, 2007), further research is required to improve understanding on structure and function. Specifically, there is a knowledge gap related to the geomorphological and climate controls on hydrological balances, which may lead to misinterpretations on the direction, magnitude, and timing of paleohydrological changes.

There are many descriptions of semidesert to desert wetlands that are directly fed by streams, snowmelt, or by an emerging water table due to the intersection of regional aquifers with the surface (e.g., Sáez et al., 2016; Herrera et al., 2016). Little information is available on modern wetlands from arid areas disconnected from regional ground-water systems and sustained exclusively by direct precipitations, however, possibly due to the fact it is less likely they will be preserved throughout geological records. Recently, Calhoun et al. (2017) described modern examples from an ecological perspective. In parallel, a specific case of temporary wetland formation was described by Melly et al. (2017), corresponding to a modern analog from a semiarid region in South Africa. The authors refer to "perched" wetlands as systems where impermeable layers close to the surface allow for wetland development in a semiarid environment.

In the Atacama Desert, one of the driest places on Earth, modern and ancient GWD are abundant in the high-Andean basins. At $3200 \mathrm{~m}$ above sea level (m asl), these occur as peat-accumulating wetlands (Andean "bofedales") on flat terrains or sloping basins of the Altiplano, sourced by springs, snowmelt, or stream discharge (Squeo et al., 2006; Schittek et al., 2015). At lower elevations, wetlands are associated with floodplains within incised fluvial valleys, or as distinct springs that run off at the base of the Andean slopes or through fault systems (Rech et al., 2002, 2003; Grosjean et al., 2005; Squeo et al., 2006; Quade et al., 2008; Gayo et al., 2012a; Sáez et al., 2016; Pfeiffer et al., 2018).

To our knowledge, paleowetlands sustained by local perched water tables remain undocumented in the Atacama Desert or the western Andean slope. This study examines geomorphological, sedimentological, and vegetational data to describe deposits associated with the active perched Humedal La Estrella wetland complex ( $3000 \mathrm{~m}$ asl, $18^{\circ} \mathrm{S}$ ), to determine the factors and processes contributing to its origin and development. More importantly, this study will explore the potential of this paleowetland as a geohistorical archive that include records of historical variations in the regional/local hydrological cycle. Finally, considering the local archaeological record, possible patterns of wetland-resource use by preHispanic societies that inhabited the highlands of the Atacama Desert are explored.

\section{REGIONAL SETTING}

\section{Geology}

The study area is located in the Arica and Parinacota region of northern Chile (Fig. 1A). Similar to the rest of the area over the central Andes west of the Cordillera, the region is characterized by four major physiographic features (Fig. 1A): the Coastal Cordillera, the Central Depression, the Precordillera (the 
foothills of the western Andes Cordillera), and the Western Cordillera (Mortimer and Saric, 1972; Paskoff, 1979; Tosdal et al., 1984; Naranjo and Paskoff, 1985; Niemeyer, 1989). This wetland complex $\left(18^{\circ} 32^{\prime} 31^{\prime \prime} \mathrm{S}, 69^{\circ} 32^{\prime} 34^{\prime \prime} \mathrm{W} ; 3300 \mathrm{~m}\right.$ asl) lies within the Precordillera region, which ranges between 2500 and $3800 \mathrm{~m}$ asl (Garcia et al., 2004). It is part of the Tignamar Basin, a 51-km-long mountainous river that originates at approximately $4300 \mathrm{~m}$ asl in the Cordillera, with an east-west orientation. It is a tributary to the San José River that drains into the Azapa Valley (Fig. 1A). Locally, the geology is dominated by the Huaylas Formation (Fig. 1B), a middle-upper Miocene fluvio-deltaic formation mainly composed of subhorizontal sedimentary deposits intercalated with tuffaceous lenses (Garcia et al., 2004). To the northwest, the Huaylas Formation covers the hillier terrain of the lower Miocene ignimbritic Oxaya Formation (Fig. 1b).

A

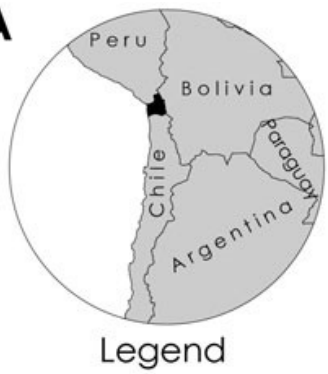

Coastal tropical desert with scarce vegetation Inland tropical deser with scarce vegetation Inland tropical thorny forest Inland tropical desert shrub Andean tropical thorny forest

Tropical Andean xerophytic dwarf shrub

Tropical Andean dwarf shrub

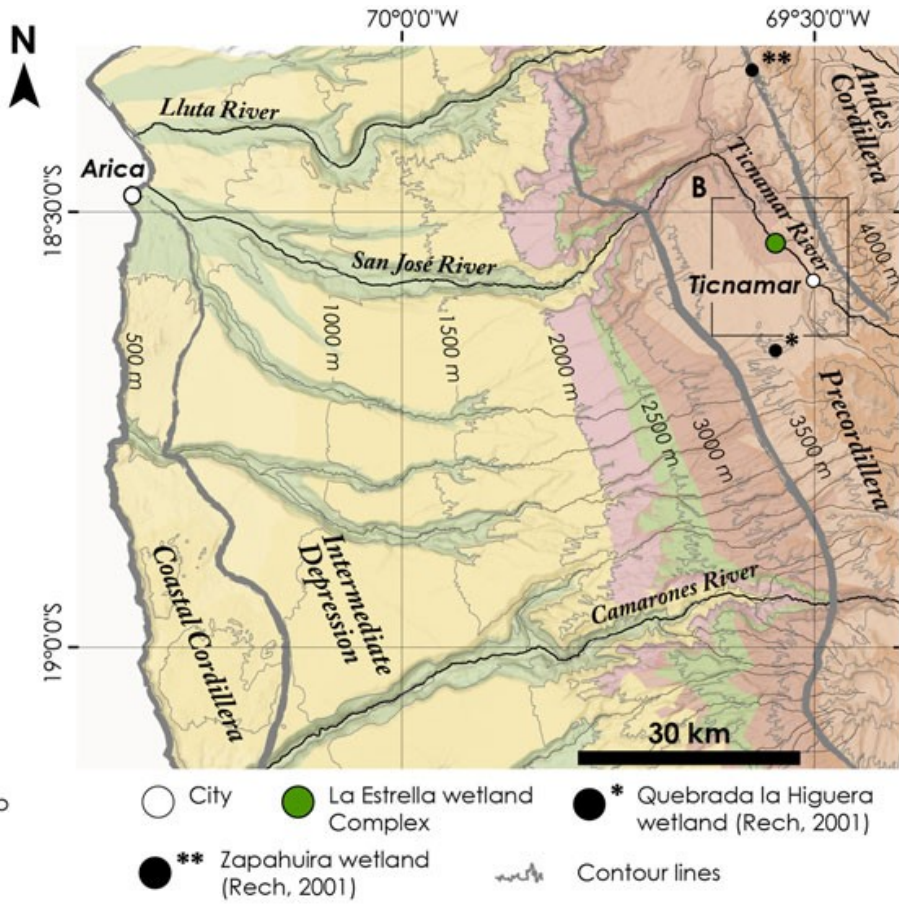

B
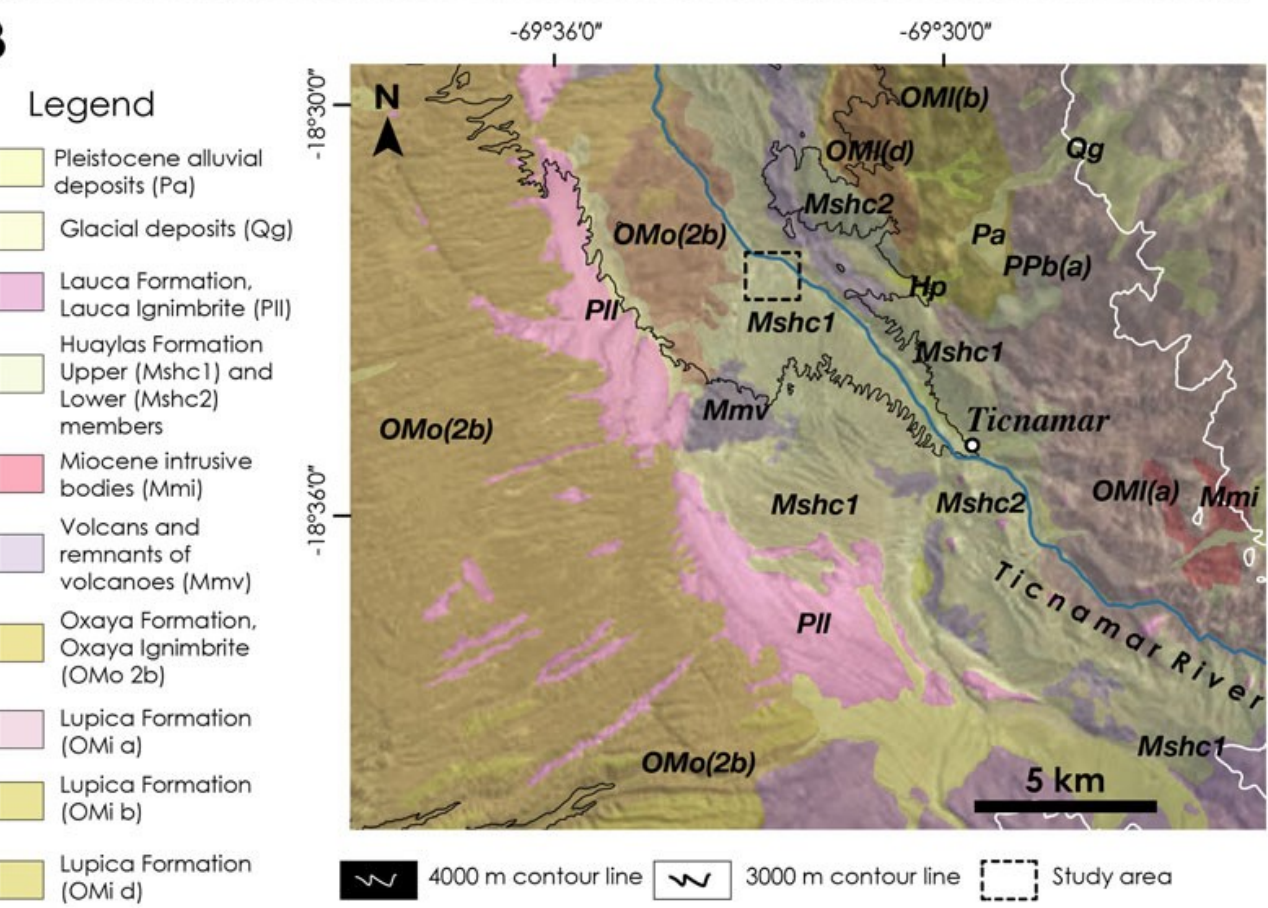

Figure 1. (A) Location map of the La Estrella wetland complex. The major regional physiographic provinces are delimited by thick gray lines. (B) Main geologic formations around the study area. Modified from Garcia et al. (2004). 


\section{Climate and hydrology}

About $80 \%$ of precipitation occurs during the austral summer (Vuille and Keimig, 2004), associated with the South American summer monsoon (Zhou and Lau, 1998) that brings moisture from the Amazon Basin and/or Gran Chaco (Garreaud et al., 2003). The high summits of the Andes generate a strong rainshadow effect that prevents the westward advection of moist air masses from eastern South America. As a consequence, the western Andean slope $\left(15-24^{\circ} \mathrm{S}\right)$ is characterized by a strong elevational gradient in rainfall amounts (Houston and Hartley, 2003), that results in intense hyperaridity $(<5 \mathrm{~mm} / \mathrm{yr})$ at elevations below $2200 \mathrm{~m}$ asl, and arid conditions $(<35 \mathrm{~mm} / \mathrm{yr})$ at $3000 \mathrm{~m}$ asl. Mean annual rainfall rapidly increases, however, from $120 \mathrm{~mm} / \mathrm{yr}$ at $3200 \mathrm{~m}$ asl to $\sim 300 \mathrm{~mm} / \mathrm{yr}$ at $5000 \mathrm{~m}$ asl. Potential evaporation rates of $>2500 \mathrm{~mm} / \mathrm{yr}$ occur across the Atacama hyperarid core ( $<2200 \mathrm{~m}$ asl), but a decrease occurs with elevation, as more moisture becomes available (Houston, 2006). Overall, potential evaporation rates decrease significantly during the summer due to increased cloudiness and the resulting effects on net radiation (Houston, 2006).

The hydrogeology of northernmost Chile consists of two major systems: the internally drained basins on the eastern flank of the Cordillera and the externally drained basins of the Andes foothills. The main exorheic basins of the region include the Lluta, San José, Vitor, and Camarones rivers, and the minor Escritos and Gallinazos basins (Garcia et al., 2004). The Azapa basin encompasses the Tignamar, Río Seco, and the San José tributaries. These watercourses are supported by discharge from unconfined aquifers contained within Quaternary sedimentary fill (DGA, 1986).

According to Squeo et al. (2006), high-altitude central Andes wetlands occur in areas where localized ground water and/or superficial discharge generate permanently waterlogged soils. Based on hydrogeological criteria, three major categories are defined: (1) sloping peatlands, fed by local flow systems including snowmelt and surface streams; (2) basin peatlands, which include cirque basins, shallow depressions, and areas of low relief related to glacier streams and regional ground-water flow systems; and (3) flat peatlands, which are fed mainly by ground-water flow systems, and partly by stream/rivers and snowmelt. The wetlands included in this study are classified as flat. This study, however, indicates that its hydrogeology is not consistent with the criteria proposed by Squeo et al. (2006). This inconsistency is not unusual, as it is recognized that several functioning features of the high-altitude central Andes wetlands remain poorly understood, such as water sourcing, response to climate variability, and spatiotemporal evolution.

\section{Vegetation}

Across the western Andean slope, the marked elevational gradient in rainfalls leads to significant spatial variations in the distribution of vegetation (Fig. 1; Villagrán et al., 1981; Arroyo et al., 1988). Hillslope vegetation, i.e., relaying on direct precipitation, is confined to elevations above $2200 \mathrm{~m}$ asl (Villagrán et al., 1981; Arroyo et al., 1988), and three main vegetation belts develop across the ascendent precipitation gradient. Between 2200 and $3200 \mathrm{~m}$ asl, the Pre-Puna belt is characterized by a sparse xerophytic subshrub with columnar cacti; above $3200 \mathrm{~m}$ asl and up to $4000 \mathrm{~m}$ asl, denser shrubland is dominated by Baccharis tola and accompanied by cacti and tussock grasses. Here, in the so-called Puna belt, primary productivity and vegetation cover peak. Finally, at elevations above $4000 \mathrm{~m}$ asl, the highAndean steppe belt is dominated by tussock grasses accompanied by and rosette plants.

Dense and highly productive wetlands typically develop associated with flooded areas at an elevation between 3200 and $5000 \mathrm{~m}$ asl (Squeo et al., 2006). Here, vegetation is mainly composed of cushion plants and some sparse grasses (Ruthsatz, 2012) with a relatively homogeneous taxonomic composition, including taxa that are widely distributed across the Andean Cordillera (Arroyo et al., 1982; Villagrán et al., 1983). 


\section{Human occupation}

The Precordillera of Arica preserves vestiges of human occupation dating back to $10.5 \mathrm{ka}$, indicating the presence of mobile groups of hunter-gatherers who first explored the region and colonized new areas of the South American continent (Santoro et al., 2016; Osorio et al., 2017). For approximately $7000 \mathrm{yr}$, these first inhabitants gradually decreased their mobility, and began to utilize sources of vegetal and animal available in the environment. This led to important changes in human-environment relation through the management of these resources, mainly camelids (Dudognon and Sepúlveda, 2016). The transition towards the Formative or Neolithic Andean in the region was so gradual that until at least 1400 $\mathrm{yr}$ it is not possible to observe significant changes in the way of life of these high-Andean populations (Sepúlveda et al., 2018). This gradual transition occurs despite interactions with other sedentary groups; potters, farmers, and pastoralists that were settled in neighboring regions (Sepúlveda et al., 2018).From the twelfth century AD onwards, large settlements indicate a novel usage of the Precordillera, related to significant agricultural and pastoral practices requiring a strong sedentary imprint formed around three principal localities with considerable farming practices in the surrounding areas(Muñoz Ovalle, 2005). Farms are related to the presence of terraces and corrals for hosting domesticated camelids (Saintenoy et al., 2017). Subsequently, the Incas settled in the region from the fifteenth century AD onwards. Finally, the Spanish conquest from the sixteenth century AD modified the pattern of local settlement, generating a reorganization of the territory and new forms of control over local production and resources.

\section{METHODS}

Areas surveys were carried out using 5-m, high-resolution Pléiades satellite images (visible and nearinfrared bands). A false infrared image (combining bands 4, 3, and 2) and the Normalized Difference Vegetation Index (Verdin, 1996) were used to delimit the wetland deposits. An initial analysis was conducted in the field through the investigation of exposures in hand-made ditches located along linear transects.

The deepest outcrop studied, Wetland Area (WA) 1d, was sampled for micromorphology with a 5-cm resolution applied for particle-size and geochemical analysis. Thin sections were prepared on six undisturbed samples according to a standard micromorphological protocol (Guilloré, 1980), with an analytic description following the terminology proposed by Stoops (2003). Soils classification in the field was based on the World Reference Base for soil resources (FAO-WRB, 2014). Grain-size samples were processed using a Horiba LA-950 laser particle-size analyzer in the PACEA laboratory (see Supplementary Information in Sitzia et al. [2017] for details on methods). Energy-dispersive X-ray fluorescence was performed using a portable SPECTRO X-SORT $(40 \mathrm{kV}, 50 \mu \mathrm{A})$ on previously ground samples, compacted into pellets. Details of the measurement protocol are given in Supplementary Table 1. Logarithm component ratios were used to analyze geochemical data as an alternative to the raw percentages, following Aitchison (1986). Multivariate analysis was carried out using the compositional biplot described by Aitchison and Greenacre (2002). Previous to the analysis, a non-parametric replacement was carried out for the null values below the detection limit, following the method by Martín-Fernández et al. (2003). Compositional data were analyzed using the CoDaPack software (Comas and Thió Henestrosa, 2011). The mineralogical composition of two samples was studied by Xray diffraction on ground sediment in a silicon calibrated PANalytical X'Pert diffractometer, using the $\mathrm{Ka} 1$ of a copper anticathode operated at $40 \mathrm{kV}$ and $40 \mathrm{~mA}$. Mineralogical identification was carried out through the comparison with the JCPDS-ICDD database using the DIFFRACPLUS Eva software.

Vegetation in the wetland complex as well as in immediately adjacent areas was characterized using the sample quadrant method. The minimal area procedure was used to estimate the quadrat size (Kent 
2011). A total of 28 quadrats were established to record the frequency and cover of each specimen and collect representative individuals for subsequent taxonomic identification. Species were identified using specialized literature and the taxonomic key proposed by Zuloaga et al. (2008). Finally, vegetation surveys are used as the basis of describing the function of the Humedal La Estrella wetland complex.

Our chronology is based on radiocarbon ages on charcoal and organic sediments collected from four sections of the paleowetland deposits (Table 3). Obtained ages were calibrated using the SHCal13 calibration curve under the Calib 7.0.4 software (Stuiver et al., 2018). In WA1d section (Figs. 2 and 3), the $2 \mathrm{~A}$ horizon was dated using both organic sediment and charcoal to evaluate the reliability of the primary provenance estimations from charcoal. Radiocarbon determinations for both samples are coherent but statistically different (t-test $=7.86, \mathrm{x}^{2}=3.84, \mathrm{df}=1$ ),yielding a pooled mean age of $325 \pm$ $20{ }^{14} \mathrm{C}$ yr BP for the $2 \mathrm{~A}$ horizon (charcoal age $=285 \pm 25{ }^{14} \mathrm{C}$ yr BP, organic sediment $=390 \pm 30{ }^{14} \mathrm{C}$ yr BP).
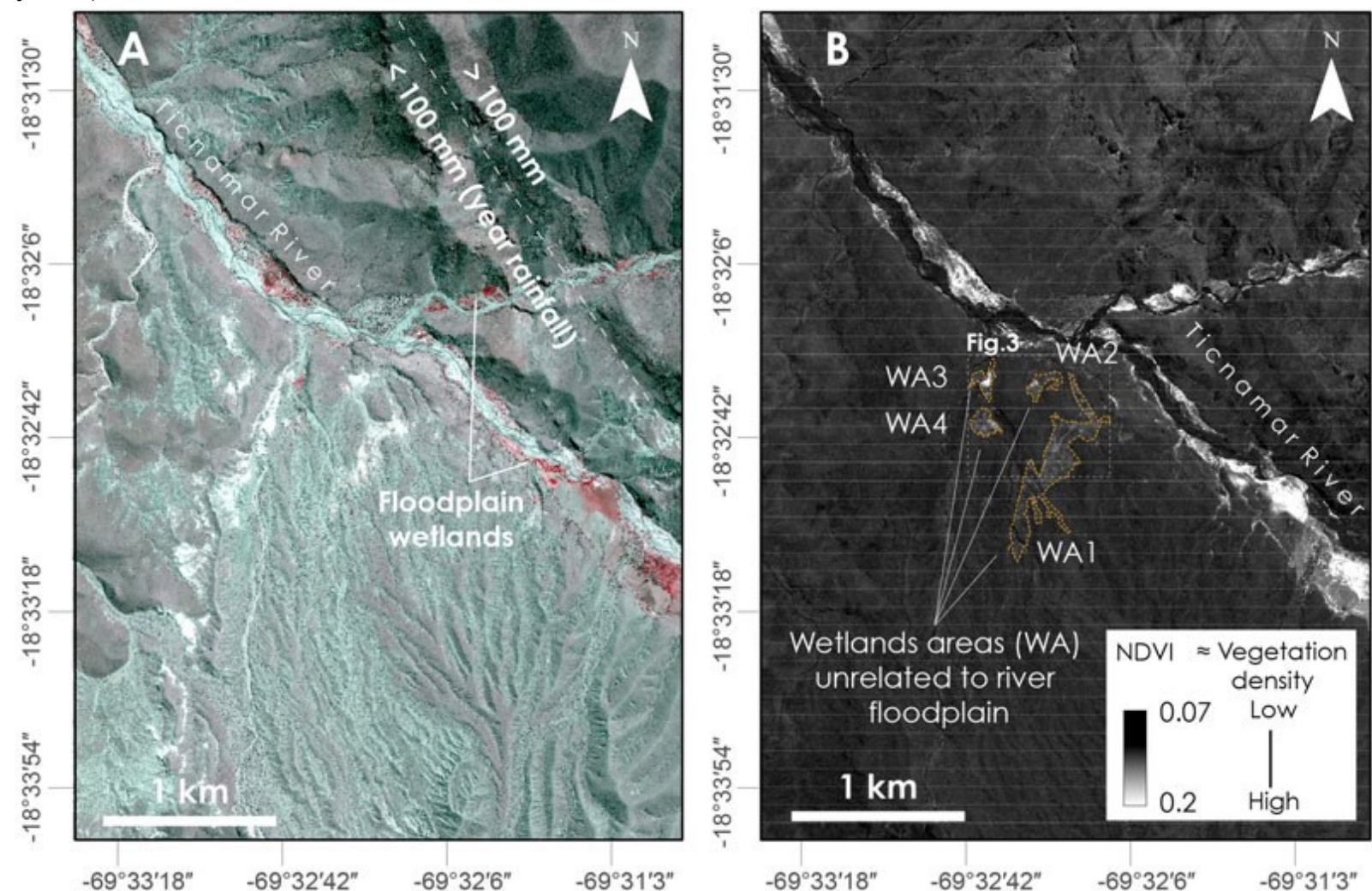

Figure 2. (A) False color infrared image. (B) Normalized Difference Vegetation Index (NDVI) map, identifying the four major wetland areas from the study. Base layer for maps: 5-m resolution Pléiades satellite image.

Systematic archaeological surveys were carried out in the Tignamar basin, as part of a wider project in the Precordillera of northernmost Chile. The prospection methods for this project are published in Saintenoyet al. (2017). The surveys contribute to understanding hunter-gatherer settlement patterns between cal. 10500 and 3500 years BP (Sepúlveda et al., 2017A, B), and sedentary and agriculture populations between the twelfth and fifteenth centuries (Saintenoy et al., 2017). The surface records correspond mainly to: (1) small isolated lithic knapping events; (2) concentrated lithic knapping areas; (3) isolated circular enclosures; (4) circular structures used as dwellings, and other complex sets of circular enclosures identified as pens, which have been defined as villages due to the presence of lithics and dispersed ceramic material; (5) parallel stone alignments interpreted as channels indicating sectors used for agricultural cultivation; (6) sloping agricultural terraces; and (7) rock-shelters with or without rock art paintings. This study reevaluates and verifies available data in the field, specifically within the 
wetland area. Four arbitrary sectors are defined within a radius of ca. $800 \mathrm{~m}$ around the wetland complex. These sectors were used to classify the archaeological findings from the surface and to discuss possible links between visible human settlement and river courses and wetlands, including the La Estrella wetland complex.

\section{RESULTS AND INTERPRETATION}

\section{Geomorphology and vegetation}

The false color infrared image (FCIR) and the NDVI map allows for the discrimination between the Tignamar River floodplain, its eastern tributaries, and four areas with intermediate values (Fig. 2A and B). As observed in other desert regions with lower vegetation density (e.g., Qi et al., 1994), areas with higher vegetation density had higher values of NDVI (Fig. 2B). The white areas appearing as an NNWSSE narrow strip in the FCIR, do not appear in the NDVI image. These areas correspond to an intercalation of volcanic tuff in the Huaylas Formation (Garcia et al., 2004) as verified in the field.

Field inspection and mapping confirm that the four areas with intermediate values are wetlands and that areas WA1 and WA2 are interconnected (Fig. 3). The geomorphological map of wetlands (Fig. 3) confirms the following: (1) internal topographic diversity, since flat areas, as well as slopes, are observed; (2) a clearly developed pattern of internal drainage; (3) the emergence of minor water rivulets at the contact between the tuff and the alluvial sediments of the Huaylas Formation; (4) wetlands are cut by small ephemeral channels, which are part of the Huaylas Formation drainage pattern (Fig.4B); and(5)wetland deposits are found on top of the tuff.

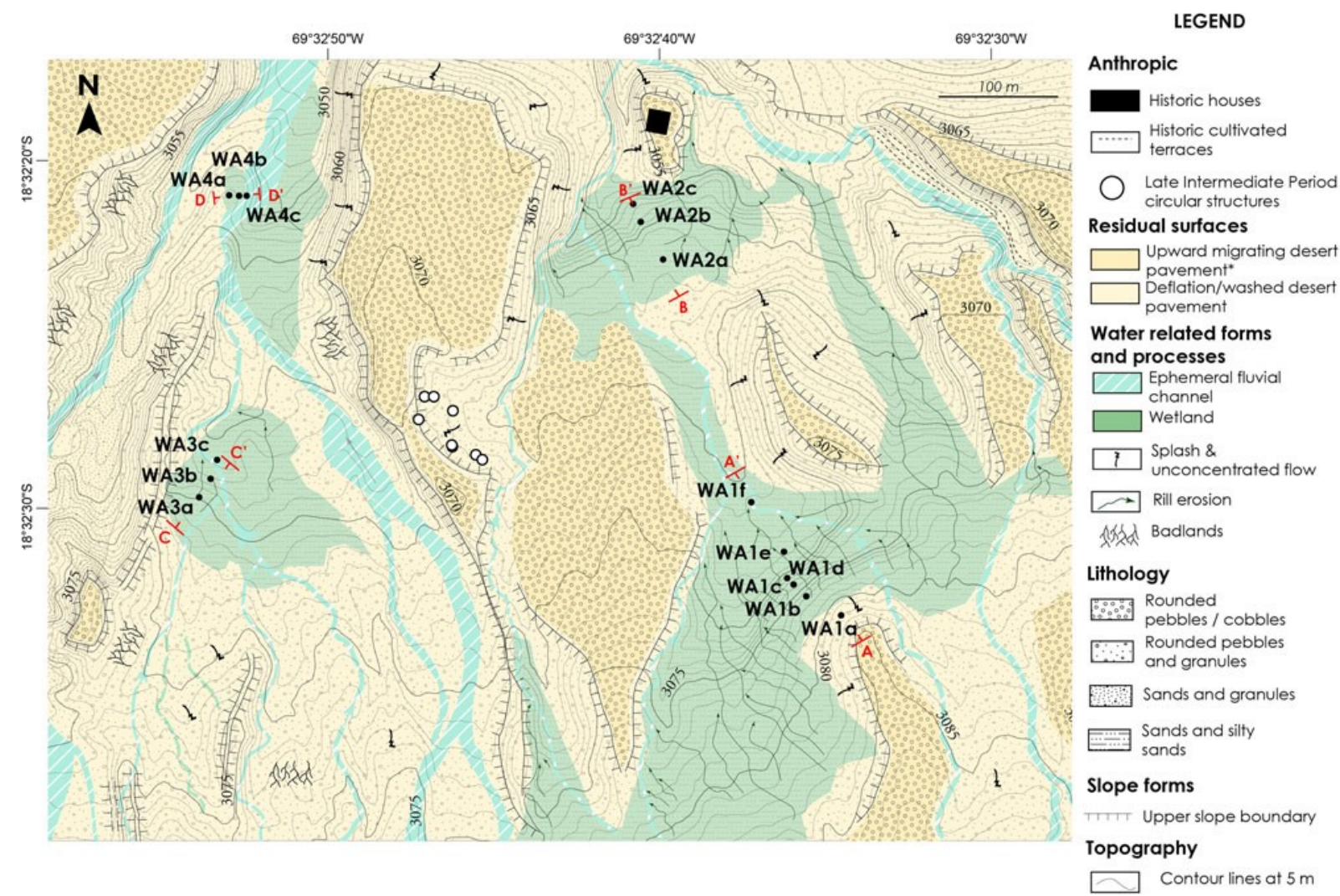

Figure 3. Detailed geomorphological map of identified wetlands (see Fig. 2c for exact map extension). Geomorphological map symbology based on Gustavvson et al. (2006). 
Vegetation composition and structure are substantially different to the high-Andean peat-accumulating wetlands (Supplementary Table 3), excluding Carex sp., Frankesia sp., Cumulopuntia sp., Stipa sp., Deyeuxia sp., and Wermeria sp., that are present in both systems. The perched wetland in this study lacks key cushion plants (Oxychloe andina and Distichia muscoides), perennial grasses (Festuca sp.), and semiaquatic taxa (Juncaceae) that are common in high elevation bofedales (Teiller, 1998; Squeo et al., 2006; Villagrán et al., 1983). In fact, halophytic taxa that dominate in hyper-saline and semipermanent flooded wetlands (e.g., Distichlis humilis, Frankenia triandra, and Carex spp.; Navarro, 1993; Buttolph, 1998; Teiller, 1998) exhibit the highest relative frequency in our studysite (Supplementary Table 3). This implies that our wetland complex should be considered as a saline wetland, similar to the wetlands within modern salars, rather than a bofedal sensu Squeo et al. (2006).

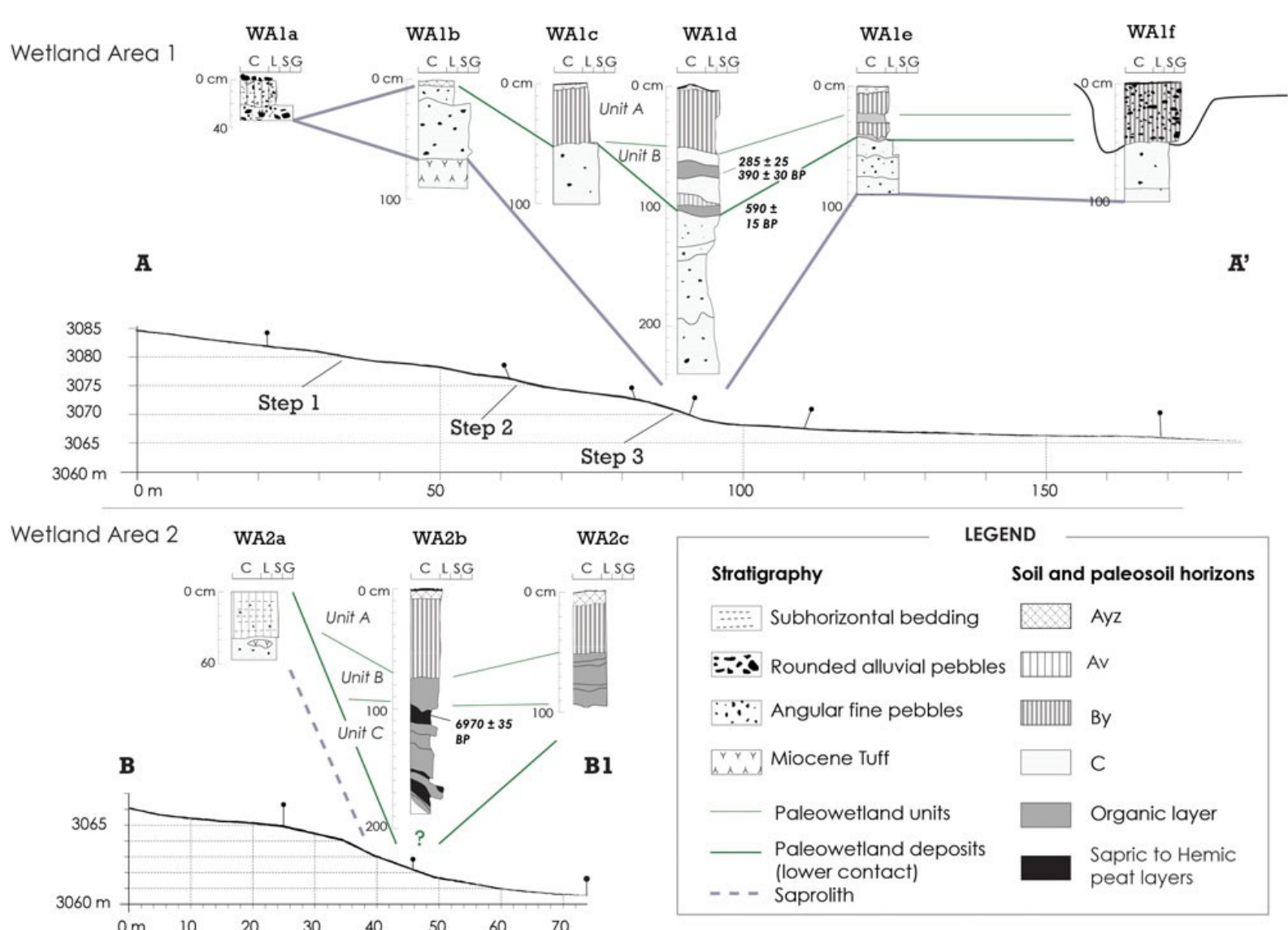

Figure 4. Synthetic stratigraphic logs of Wetland Areas (WA) 1 and 2.

\section{Stratigraphy and soil description}

Paleowetland deposits have been divided into three main pedostratigraphic units (A, B, and C) based on stratigraphic and soil description. Seven radiocarbon ages (Table 1) on charcoals and organic sediment from paleosols in sections WA1d, WA2b, WA3b, and WA4b (Fig. 4 and 5) verify the stratigraphy observed in the field. The following section provides a brief description of the Miocene tuff intercalation and the characteristics of Units C, B, and A (from oldest to youngest, respectively). Reference is made to the WA1d section (Fig. 6), while the results and a description of grain-size and geochemical analysis are detailed in the Supplementary Information. 


\begin{tabular}{|c|c|c|c|c|c|c|}
\hline Site & Lab code & Material & $\delta^{13} \mathrm{C}(\%)$ & $\begin{array}{c}\text { Age } \\
\left({ }^{14} \mathrm{C} \text { yr BP }\right)\end{array}$ & $\begin{array}{l}\text { Calibrated Age } \\
\text { (cal yr BP) }\end{array}$ & $\begin{array}{l}\quad \text { Median } \\
\text { Calibrated } \\
\text { Age } \\
\text { (cal yr BP) }\end{array}$ \\
\hline Humedal La Estrella - WA1D - C3 & Beta-441609 & Charcoal & -33.3 & $390 \pm 30$ & $490-320$ & 400 \\
\hline Humedal La Estrella - WA1D - C2 & UCIAMS-165620 & Charcoal & - & $590 \pm 15$ & $560-530$ & 545 \\
\hline Humedal La Estrella - WA1D - C1 & D-AMS 027605 & Sediment & - & $285 \pm 25$ & $440-155$ & 300 \\
\hline Humedal La Estrella - WA2B - C1 & D-AMS 027604 & Sediment & - & $6970 \pm 35$ & $7850-7670$ & 7755 \\
\hline Humedal La Estrella - WA3B - C1 & D-AMS 027603 & Sediment & - & $400 \pm 20$ & $495-330$ & 440 \\
\hline Humedal La Estrella - WA3B - C2 & D-AMS 027602 & Sediment & - & $1375 \pm 25$ & $1300-1190$ & 1270 \\
\hline Humedal La Estrella - WA4b - C2 & D-AMS 027601 & Sediment & - & $6410 \pm 30$ & $7420-7180$ & 7300 \\
\hline
\end{tabular}

Table 1. Radiocarbon ages. Calibration was made using SHCal13 and Calib software. The ${ }^{13} \mathrm{C}$ values used for correction were not available in the radiocarbon dating report from the Direct AMS laboratory.

\section{Miocene tuff intercalation}

In the WA4c section (Fig. 5), the top of the Miocene tuff intercalation is characterized by several sandy $\mathrm{C}$ horizons that overlie a pale red uncemented ash horizon with abundant gravels (lapilli, lithic fragments), and unaltered R-horizon patches (Supplementary Fig. 1f). In the WA1d section, the top of the Miocene tuff corresponds to horizons 4C, 4C1, and 4Cg2 (Fig. 6; Supplementary Fig. 1a). The horizons are silty clay sand to silty sand with common gravels (lapilli and lithic fragments), and the grain-size analysis and ternary principal component confirms linearity in the relative sand variation with respect to silt and clay (e.g., Eynatten et al., 2003; Supplementary Table 2). The micromorphological sample from the $4 \mathrm{C} 1$ horizon presented a vughy to channel microstructure, eventually granular (Supplementary Fig. 2). The channel microstructure was related only to the roots inside the groundmass, and not to faunal activity (Supplementary Fig. 2). The mineral fraction is dominated by quartz, Kfeldspars and kaolinized plagioclases, and there are small lithics and other volcanic elements, such as shards, pumice, flames, and spherulite. Carbonate impregnation dominates over gypsum pedofeatures. The micromass has acalcitic crystalline undifferentiated b-fabric, with dissolution features such as a lenticular mold of gypsum crystals inside carbonate nodules (Supplementary Fig. 2). 


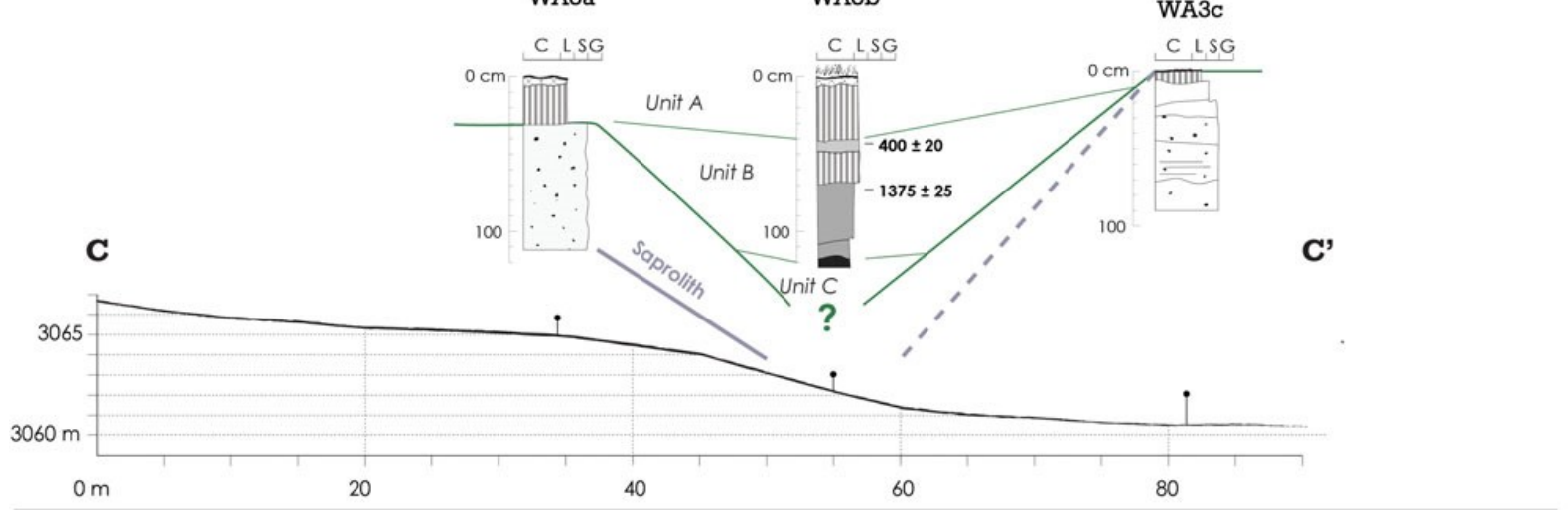

Wetland Area 4

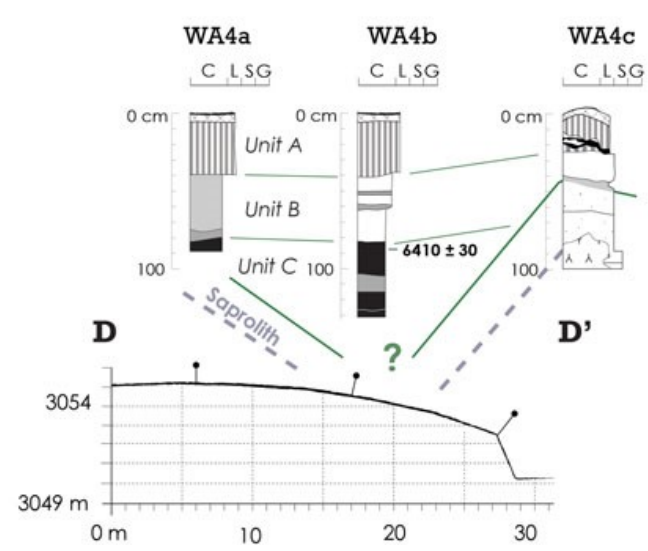

LEGEND

Stratigraphy

Soil and paleosoil horizons

....... Subhorizontal bedding

Ayz

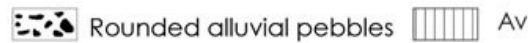

$\because \because$ Angular fine pebbles

$\left[\begin{array}{ccc}2 & x \\ x & y & y \\ x & x\end{array}\right]$ Miocene Tuff

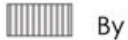

- Paleowetland units

C

Paleowetland deposits (lower contact)

Organic layer

- - - Saprolith

Sapric to Hemic peat layers

Figure 5. Synthetic stratigraphic logs of Wetland Areas (WA) 3 and 4. 

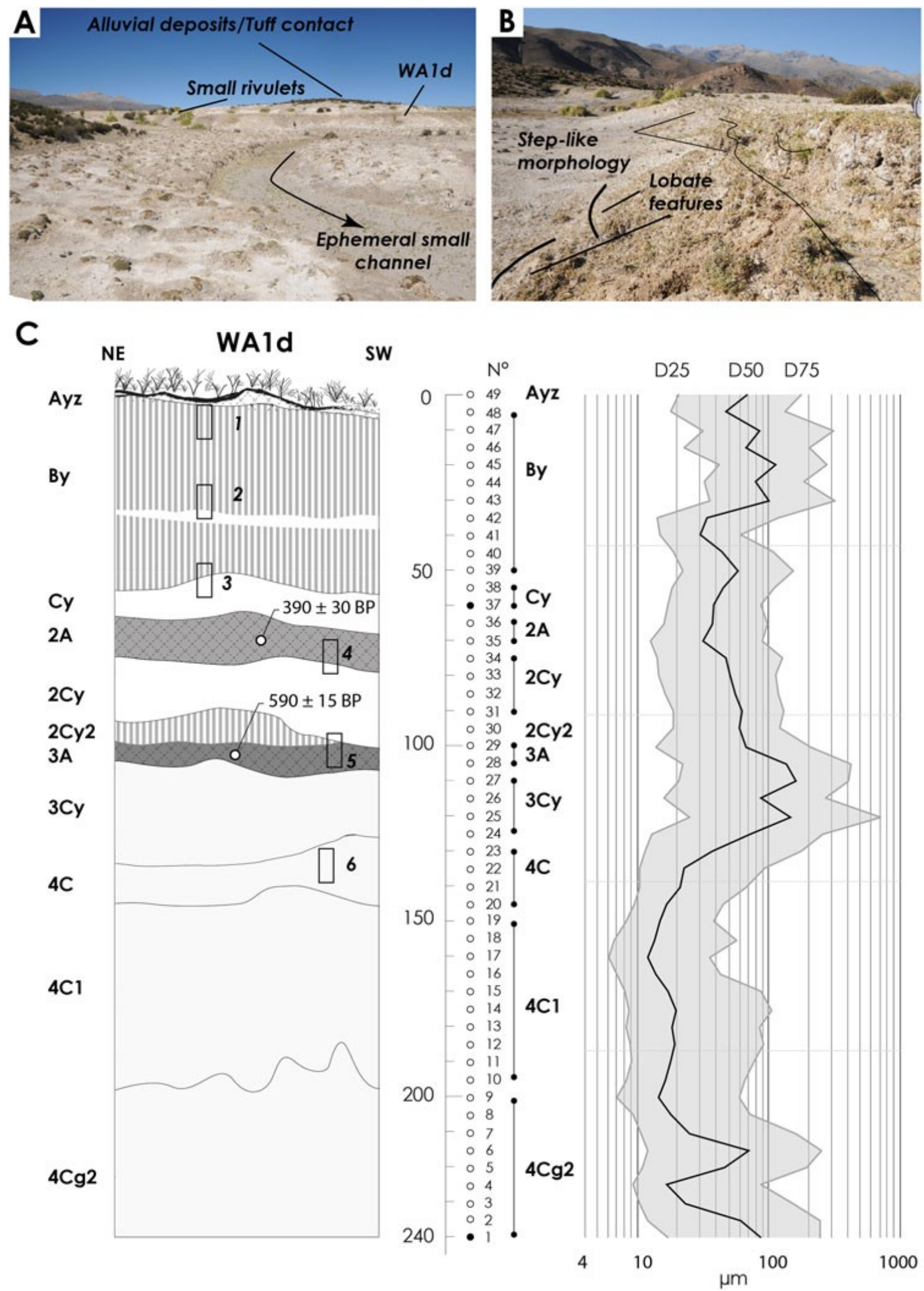

Figure 6. Wetland Area (WA) 1. (A) Panoramic view facing southeast and the position of the WA1d outcrop. (B) Detailed view of the second step slope, with evidence of crown cracks on the top and lobate features in the footslope. (C) Left: stratigraphic profile with position of micromorphological samples (rectangles). Right: diagram of grain-size variation along the sequence expressed by particle diameters at the $25^{\text {th }}, 50^{\text {th }}$, and $75^{\text {th }}$ percentiles (D25, D50, and D75, respectively). Dots indicate grain-size samples, the black dot indicates the X-Ray Diffraction (DRX) analysis. 
We suggest that, below the paleowetland deposits, there is a saprolith profile resulting from the weathering of the original Miocene tuff intercalation. Layers $4 \mathrm{C} 1,4 \mathrm{C} 2$, and $4 \mathrm{Cg} 2$ in the WA1d section are $\mathrm{C}$ horizons because they lack clear structure and have few pedogenic features (small roots channels, carbonate, and gypsum concretions). The presence of shards, flames, spherulites, pumice, and lithics confirm a parent material of volcanic origin (Scasso and Limarino, 1997; Vaniman, 2006). The grainsize linearity in the ternary principal component analysis of sand to silt and clay and the D25-D50-D70 size trend along the horizons, and are assumed to be the result of glass weathering and the fragmentation of less resistant minerals within the tuff (Dubroeucq et al., 1998; Yokota and Iwamatsu, 2000). Geochemical results reinforce the saprolith interpretation. All the samples from the $4 \mathrm{Cg} 2$ horizons are clustered around $\mathrm{Si}$ and $\mathrm{K}$ values (Supplementary Table 2), which suggest a greater abundance of alterable minerals such as feldspar and muscovite as well as a concentration of unaltered minerals such as quartz. These minerals were recognized in the thin sections (Supplementary Table 1) and the X-ray diffraction analysis (Supplementary Table 2). In the WA4c section, the horizons below Unit A and B are considered to be part of the saprolith and the $\mathrm{C}$ horizons are the saprolite, whereas the horizon that hosts patches of relatively unaltered bedrock is the saprorock; the R horizon, which corresponds to a cemented ash with abundant lapilli and lithic fragments, is the unaltered Miocene tuff (Supplementary Fig. 1f).

The gleyey conditions of the lowermost horizons from the WA1d and WA4c sections confirm waterlogging. This is also supported by the detection of pyrite mineral in the X-Ray Diffraction (DRX) samples from $4 \mathrm{Cg} 2$ in the WA1d section (Supplementary material Fig. 5), since pyrite forms under anoxic conditions in wetlands (e.g., Vepraskas and Faulkner, 2000).

\section{Unit C}

Unit $C$ is a histic horizon that varies from 10 to $100 \mathrm{~cm}$ thick according to the section. It is not possible to estimate the maximum thickness, as the base of the unit was not observed. In WA2, the horizon is characterized by curved decimetric parallel layers and shows the following alternations: (1) massive muddy sapric to hemic peat layers; and (2) laminated silty to muddy organic layers, with lenticular powdery gypsum parallel to the laminae (Supplementary Fig. 1d). In WA4, the horizon shows an internal sequence of layers that are centimetric to decimetric and are organic or organo-mineral (Supplementary Figure 1e). The top layer of this horizon has an internal lamination, with some laminae made up of lenticular powdery gypsum (Supplementary Fig. 1e). The top of the $\mathrm{H}$ horizon is dated within the sections WA2b and WA4b, indicating a maximum age of 7755 to $7300 \mathrm{cal}$ yr BP for Unit C. Unit C is considered to represent a phase of wetland recharge that was sufficient to permanently raise the local water table and peat accumulation.

\section{Unit B}

Unit B is 25 to $80 \mathrm{~cm}$ thick and is characterized by a succession of silty to sandy silt A horizons separated by silty to sandy silt C horizons (Fig. 5 and 6; Supplementary Figs. 1a-e). Results from the WA1d section indicate that samples from this unit group around the compositional pole of $\mathrm{Ca}-\mathrm{As}$, predominantly related to gypsum and calcite (Supplementary Table 2). The most abundant mineral is quartz, followed by kaolinized K-feldspars and plagioclases (Supplementary Table 1). All the horizons contain volcanic elements in the form of lithics, shards, pumice, flames, and spherulites (Supplementary Figs. 3.1-11). Horizons 2A and 3A contain evidence of preserved organic material and charcoal (Supplementary Fig. 3). Horizon 2A contain partially to nearly fully decomposed organic material (Supplementary Fig. 3.15). Horizon 3A has abundant organic material corresponding to: (1) minimally to partially decomposed roots (classes 1 to 3 of Blazejewski et al., 2005; Supplementary Figs. 3.14, 4.1- 
2); and (2) phytoliths (Supplementary Figs. 4.3-5). Gypsum pedofeatures, such as infillings, coatings, and nodules dominate in the upper horizons (Ayz-By-Cy; Supplementary Figs. 4.7-11), whereas towards the base of the section there is an increase in carbonate impregnation (Supplementary Fig. 4.6). The micromass includes a gypsum crystallitic undifferentiated b-fabric.

The two paleosols that were investigated in the WA1d section (2A-2Cy-2Cy2 and 3A-3Cy) were formed on parent material of volcanic origin according to the mineral fraction (Supplementary Table1). The basal paleosol (3A and3C) is preliminarily considered as an Epileptic Tephric Histosol (FAO-WRB, 2014). This paleosol has a loose microstructure with abundant tephric material, small decomposed organic fragments in the coarse fraction, and an absence of mesofauna/macrofauna action (Babel, 1975; Stolt and Lindbo, 2010). The last two attributes are thought to reflect permanent or semipermanent saturated soil surfaces (Stolt and Lindbo, 2010). It is proposed that the $3 \mathrm{~A}$ paleosol indicates a period of significant wetland recharge. The lack of a gypsic horizon or significant gypsum concretions associated with the histosol reinforces the notion that this recharge event was sufficient to cause a permanent rise in local water tables. The upper paleosol (2A-2C) is poorly developed and lacks diagnostic horizons. Based on these criteria it is classified as a Tephric Humic Regosol (FAO-WRB, 2014). Weak pedogenesis is demonstrated through a humic horizon with sparsely distributed organic materials consisting of altered fragments and rare charcoals. This paleosol was preserved by an associated episode of ash fall, effectively sealing the $2 \mathrm{~A}$ and $2 \mathrm{C}$ horizons.

Unit $B$ is believed to correspond to a sequence of several tephric humic regosols and/or tephric histosols, representing episodes of permanent rises in local water tables. Paleosols are less organic than the underlying Unit $\mathrm{C}$, and are associated with a younger pedogenesis, indicated by radiocarbon dates. Overall, Unit B accumulated between ca. 7300 and ca. $300 \mathrm{cal} \mathrm{yr} \mathrm{BP.} \mathrm{Thus,} \mathrm{the} \mathrm{volcanic} \mathrm{material}$ composing the paleosols derives from fresh ash-fall inputs from regional volcanic eruptions dating to the Mid-Late Holocene.

\section{Unit A}

Unit $\mathrm{A}$ is 20 to $80 \mathrm{~cm}$ thick and corresponds to the present soil and is characterized by the horizons Ayz, By, and Cy. Analysis from the WA1d section shows that the microstructure is fine monic to crumb from Ayz to Cy (Supplementary Fig. 2). The crumb microstructure does not appear to be related to faunal activity since faunal pedofeatures are not observed. The mineral fraction is dominated by gypsum, followed by kaolinized K-feldspars and plagioclases. All the horizons contain volcanic elements in the form of lithics, shards, pumice, flames, and spherulite (Supplementary Figs. 3.1-11). A compositional biplot of geochemical data indicate that the horizons Ayz to Cy cluster around the Ca-As compositional pole, related primarily to gypsum and calcite according to DR and micromorphology results (Supplementary Table 2). The semiquantitative approach to noncalibrated elements indicate the following results (Supplementary Table 2): (1) $\mathrm{Cl}$ is abundant in the Ayz horizon and is related to halite; (2) Gypsum increases from By to Cy, indicated by the presence of sulfur.

Ayz, By, and Cy horizons are interpreted as a Gypsisol, identified through the criteria from micromorphological and geochemical results (FAO-WRB 2014): (1) the earth fraction exceeds 5\% gypsum, and reaches $90 \%$ in the thin Ayz layer; (2) accumulation of secondary gypsum, as infillings, coatings, nodules, and crystal intergrowths (Poch et al., 2010); and (3) gypsum soils of $>15 \mathrm{~cm}$ thick in arid to semiarid environments (Porta and Herrero, 1990; Casby-Horton et al., 2015). Here, the origin of gypsum is not related to gypsum rocks, which are absent from the area. $\mathrm{Ca}^{2+}$ and sulfate ion $\mathrm{SO}_{4}^{2-}$ enrichment is predominantly related to inputs from fresh ash fall and the altered ignimbrite. Indeed, volcanic ash deposits with adsorbed volatiles indicate the incorporation of elements such as $\mathrm{F}, \mathrm{Cl}, \mathrm{Ca}$, $\mathrm{Na}$, and $\mathrm{S}$ into the ground (Witham et al., 2005). The increased calcite content towards the base of the 
gypsisol, present in the WA1d section, suggests that the precipitation of gypsum is related to the capillary rise of a high water table (Birkeland, 1984). Due to lower solubility, calcium carbonate usually exceeds the gypsum minerals in soils, where the dominant water movement is downward (Casby-Horton et al., 2015). This may also explain the high abundance of halite in the Ayz horizons, which is considerably more soluble in comparison to the gypsum and calcite.

\section{Human settlement}

Sector 1 is characterized by several isolated lithic knapping events (basalt, andesite, and smaller amounts of chert). At its center, between WA1 and 3, eight variously sized scattered circular structures were found (Figs. 7 and 8). It is highly likely that these units had a residential function, indicated by the presence of ceramic fragments which are attributed to the "Charcollo" style from the Late Intermediate period (AD 1200-1450; Flewett et al., 2016). The size of the structures and visible deposits on the surface indicate the presence of temporary residences. This collection is interpreted to be an "estancia" (small farm) possibly related to pastoralist practices during pre-Inca times (twelfth-fifteenth centuries). The identification of small structures, identified as "windbreaks," typically built as a temporary shelter by pastoralists or caravaneers (Muñoz and Briones, 1996), confirms the hypothesis that this area was used for transitory or short-term occupations. Furthermore, a fragment of a historical turned ceramic recovered within one of the structures indicates use of the structure during more recent times. Two rectangular structures were found in association with cultivation fields close to the edge of the left bank of the Tignamar River, northeast of the main wetland. Nevertheless, these are historical structures with evidence of use during more recent times because of the presence of abandoned cans and ceramic fragments assignable to the post-seventeenth century. 


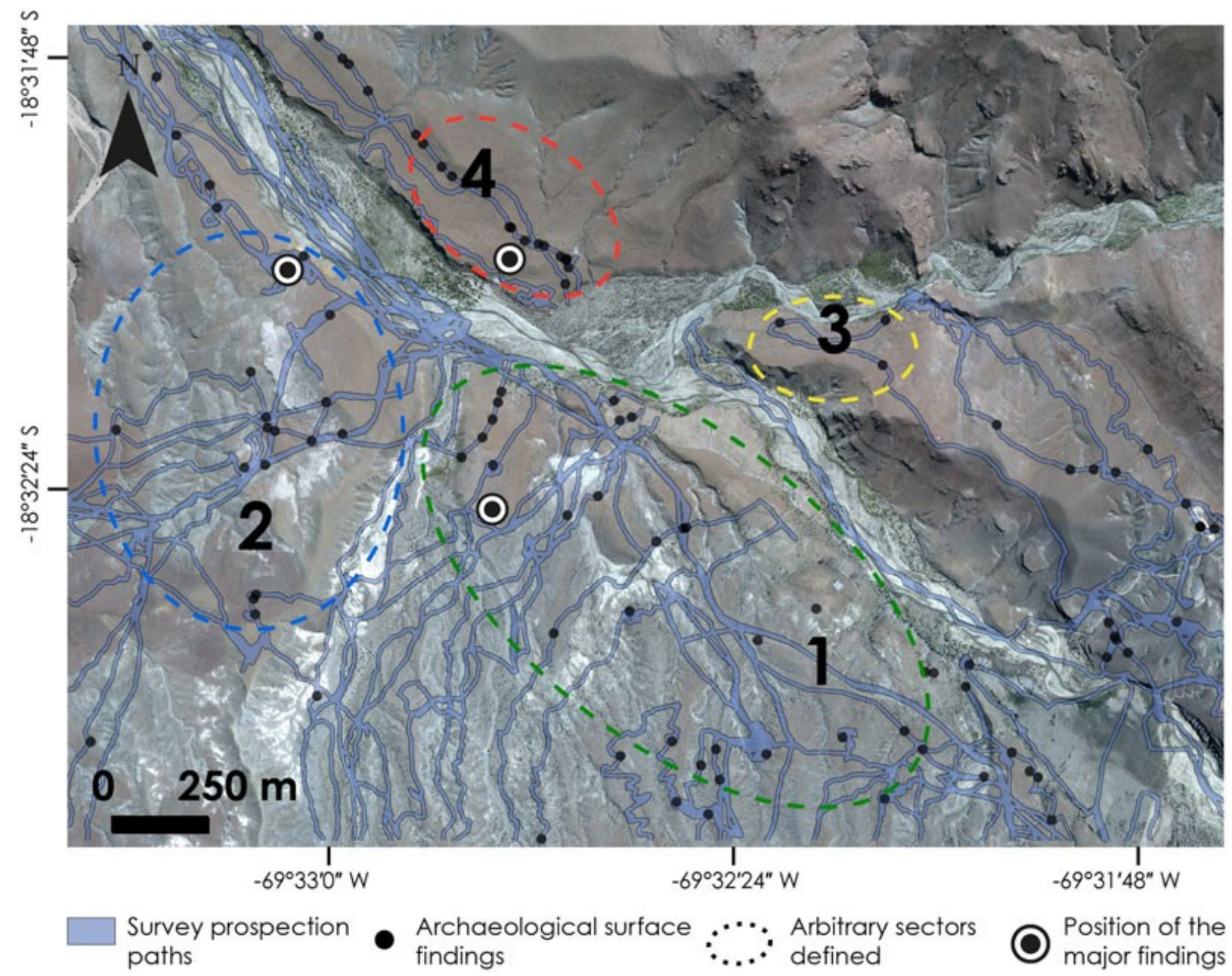

Figure 7. Archaeological findings identified from the surface within a radius of approximately $800 \mathrm{~m}$ from the wetland complex. 

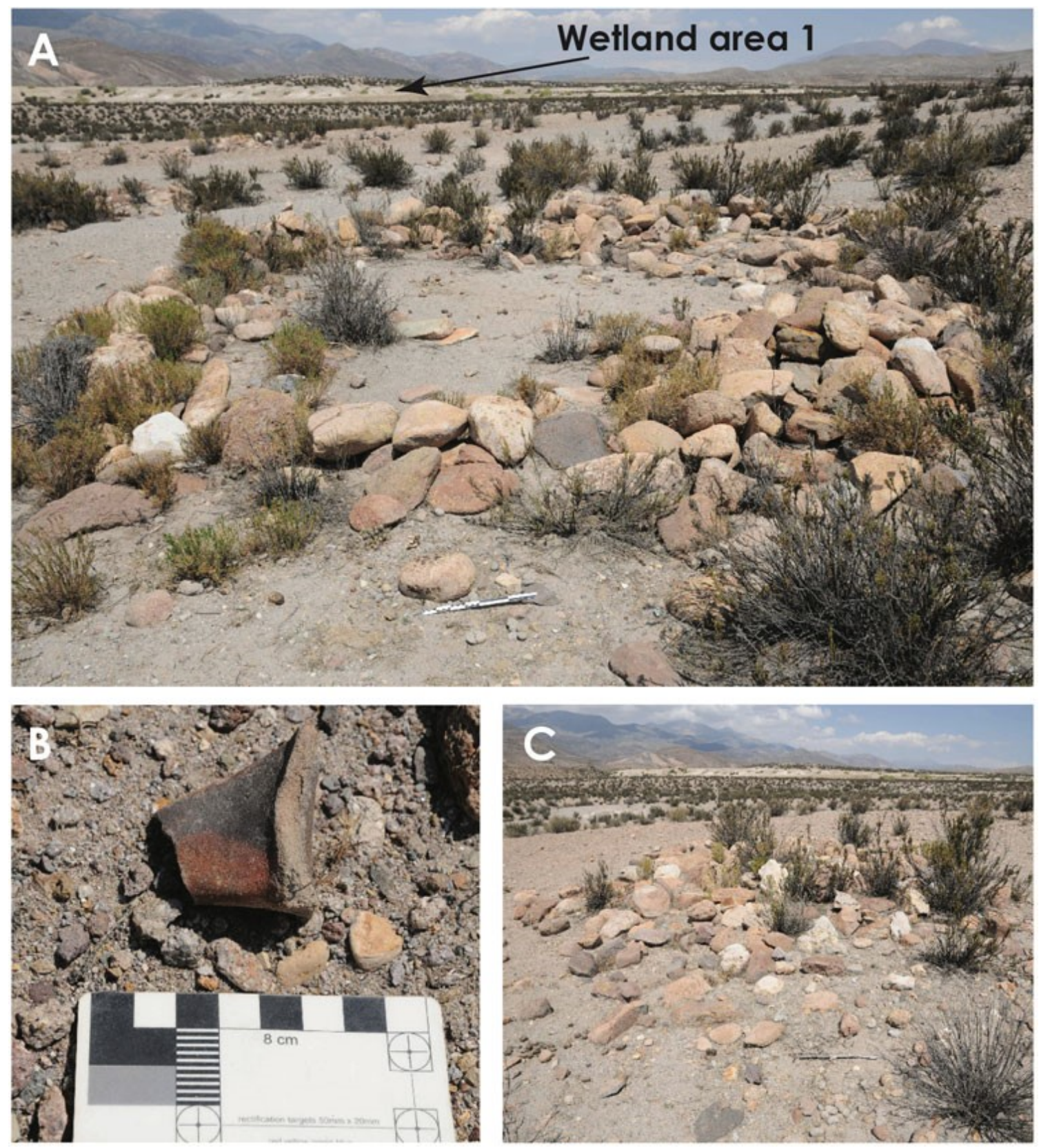

Figure 8. (A) Large sub-circular archaeological structure identified to be residential and part of a "small farm" located inside the wetland complex from the Late Intermediate or Late Period (cf. Fig. 7 for the location). Note the proximity of Wetland Area 1 in the background. (B) Fragment of a handle from a "Charcollo" ceramic found in the structure identified in A. (C) Small circular structure.

Few lithic flakes were found in Sector 2, corresponding to scattered areas of knapping activity. On the hill overlooking the left bank of the river, two small circular structures were identified, likely residential. Here, several fragments of "Charcollo," traditional ceramics from the Late Intermediate period (Flewett et al., 2016) and flakes of lithic material (andesitic-basalt and chert) were found. This site is interpreted to be an estancia of the same age as the one observed in Sector 1. In Sector 3, some ceramic fragments and scattered lithic events were observed associated with a few habitation structures, with no elements to indicate chronological origin.

In Sector 4, we recorded a considerable amount of scattered ceramics and lithics extending approximately $1.4 \mathrm{~km}$ along the hilltop overlooking the right bank of the Tignamar River. Some lithics 
and ceramics sherds are more concentrated around circular residential structures. Larger circular stone structures were also identified, which were likely used as corrals for domestic camelids. The diagnostic analysis of these ceramics indicate they originate from the Late Intermediate period, contemporary with the structures in Sector 2. Archaeological evidence suggests that this sector represents a pastoral "estancia," probably occupied by a few inhabitants working in the management of livestock. Some similarities are observed, however, between this site and the settlement found in sector two in terms of site functionality, indicating more intense pastoral activities probably due to the higher water availability. The geology in this sector is characterized by the outcropping of tuff intercalation (Fig. 6, Supplementary Table 2$)$, and NDVI values $(\simeq 0.2)$ indicating dense vegetation around this estancia, situated next to a small stream (Fig. 6, Supplementary Table 2). It is likely that the existence of the outcropping tuff was crucial to the existence of the estancia and the wetland. For instance, to the east another small stream was identified that lacks associated archaeological structures and exhibits low NDVI values $(\simeq 0.07)$, suggesting that the mere existence of surficial runoff is not sufficient to sustain productive habitats for human activities.

\section{DISCUSSION}

\section{Hydrologic interpretations}

Mapping, geomorphological, and vegetation data confirm that the wetland complex has an unusual hydrologic setting: the water inflow can neither be related to an alluvial system, nor to seasonal melting of snow patches or spring water. Presently, the only perennial river in the area is the Tignamar, which is fed by streams from the Cordillera, where higher precipitation occurs (Ayala et al., 2003). The high drainage density pattern which typifies the Huaylas Formation, west of the Tignamar River, is inactive. Runoff waters during summer storms are able to produce channelized shallow water flow, but low annual precipitation and high evapotranspiration prevents river formation. Despite the fact, this wetland results from a long-term temporal evolution; an alluvial origin is excluded, since none of the described sections show stratigraphic evidence of fluvial facies within wetlands deposits. Thus, this system is sustained by water input from direct rainfalls; but also through a local perched ground-water system which retains water and feeds the wetlands ecosystem. The first condition is confirmed by the present rainfall $(<100 \mathrm{~mm})$, whereas the second condition still needs to be confirmed. A shallow local ground-water system implies a lower boundary in the form of aquitard, deeper ground-water systems emerging at the surface, or an impermeable barrier (Townley, 1998). There are no spring waters (i.e., a deep seated bedrock aquifer emerging at the surface) in the Tignamar basin, as annual precipitation in the area is not sufficient to feed deep aquifers even if we consider contributions from snowmelt. Meteorological evidence, however, precludes the influence of such factor, as at $3000 \mathrm{~m}$ asl there is less than a $20 \%$ probability for snowfalls across the tropical-arid Andes (Vuille and Ammann, 1997). Hence, the most plausible explanation is the existence of an impermeable barrier.

The local thin tuff intercalation may act as an obstacle to water percolation, especially considering the systematic overlap between the wetland areas and the tuff. According to Garcia et al. (2004), the intercalation is moderate to non welded. The hydrologic properties of tuffs depend on their welding degree (Smyth and Sharp, 2006). Porosity and permeability are high in non-welded tuffs, while their values significantly diminish in densely welded tuffs (Smyth and Sharp, 2006). There is no analytical data on the hydrological parameters for the tuff, but results from the stratigraphic sections indicate that it acts as a barrier. In the WA1d section, the $4 \mathrm{Cg} 2$ horizon corresponds to the ground water or saturated 
zone, while the 4C and 4C1 horizons are in the vadose zone. This configuration is only possible under the conditions of the unaltered tuff acting as an aquiclude deeper in the stratigraphy.

In summary, the local hydrological cycle is best described through considering the current precipitation regime, the topographic and geomorphological conditions within the wetland complex, and inferring the existence of a local low permeability barrier (Fig. 9A). During the rainy season (NovemberMarch), precipitation percolates through the wetland topsoil until it reaches the tuff barrier or, eventually, the saturated zone above it. The local shallow ground-water table recharges and moves vertically through the surface, facilitating short periods of water saturation near the surface of the soil. Water emerges along small ravines that dissect the wetlands (Fig. 9A), and surface flow has also been observed over smallscale slope breaks inside the wetlands, such as in WA1, 2, and 3. It is probable that runoff generated upstream during intermittent heavy rainstorm events delivers water and sediments to the wetlands. This mechanism is supported by field observations made within some study sections that verify subhorizontal bedding or sandy layers in the upper part of the stratigraphy (Fig. 4 and 5). Throughout the dry season (April-October; Fig. 9B), water tables gradually drop as evapotranspiration rates increase regionally (Houston, 2006). 


\section{A LA ESTRELLA FLAT PERCHED WETLANDS CURRENT ANNUAL CYCLE}
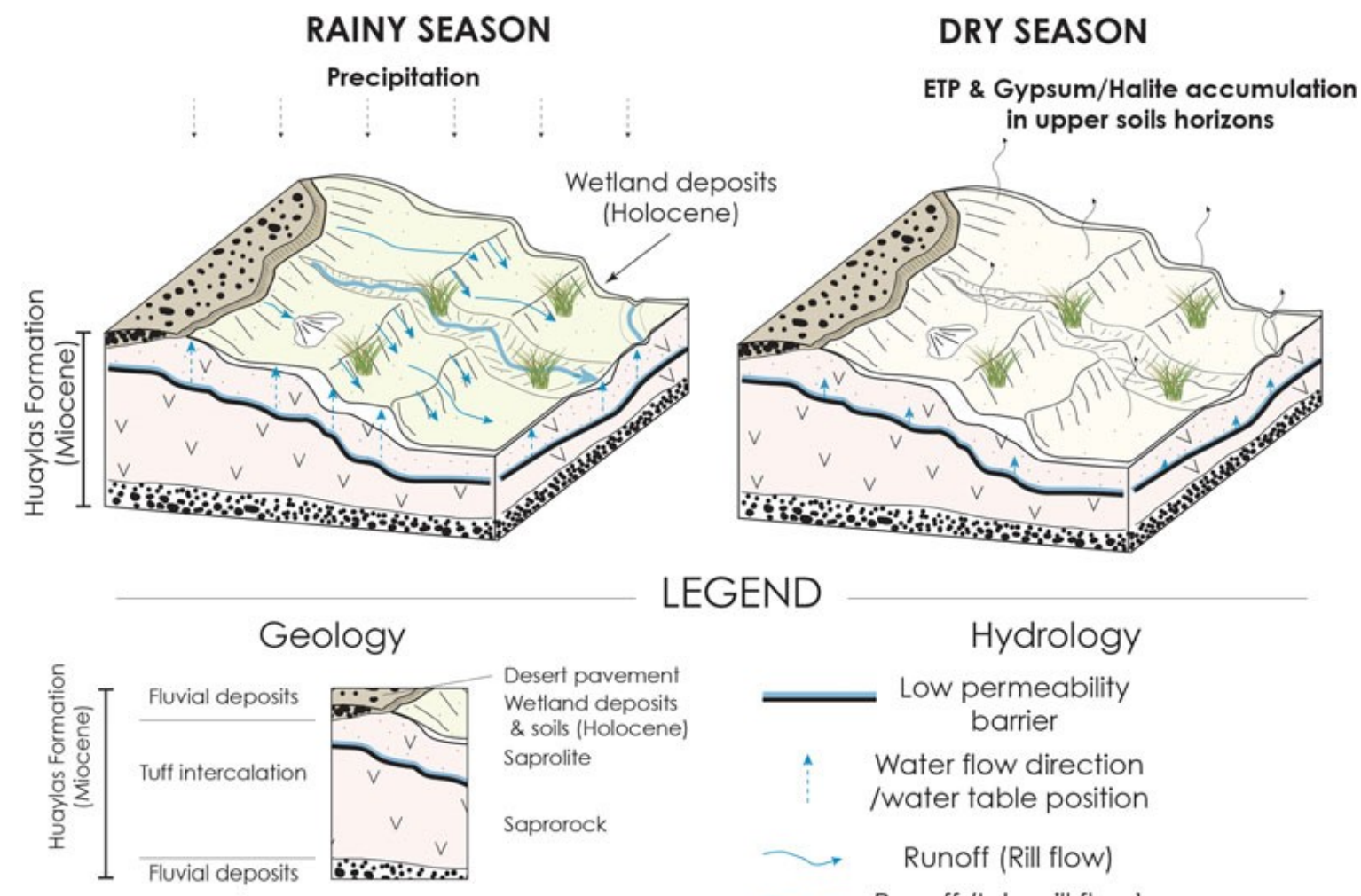

\section{LEGEND

$$
\text { Hydrology }
$$

Low permeability

$$
\text { barrier }
$$

Water flow direction

/water table position

$\longrightarrow$ Runoff (Rill flow)

$\longrightarrow$ Runoff (Inter-rill flow)

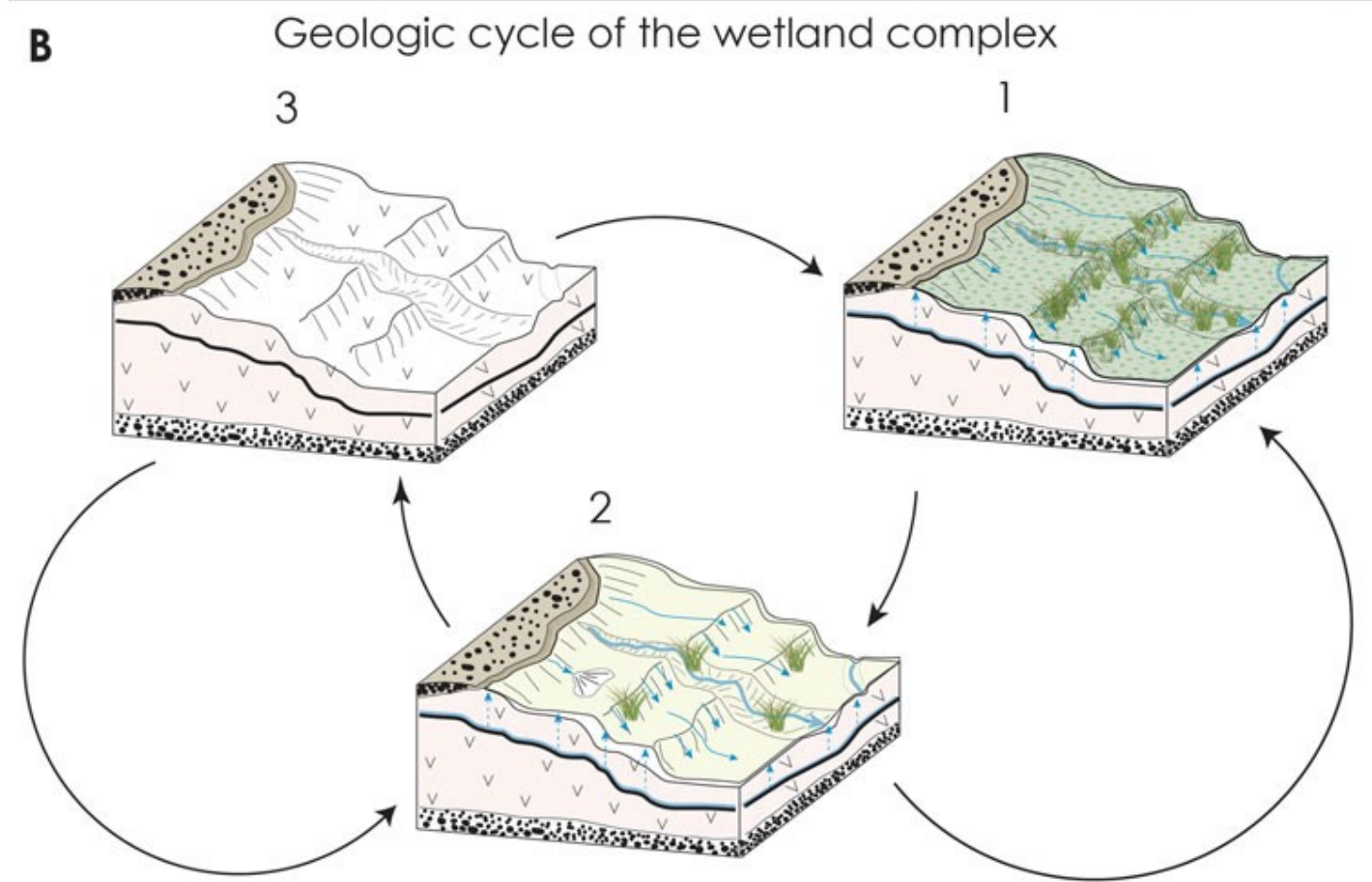

Figure 9. (A) Synthetic model of current annual cycle in the Humedal La Estrella wetland complex. (B) A model of the geologic cycle of the wetland complex over time. Arrows indicate possible repetitions during the cycle, suggesting that the wetland cycle depends on corresponding changes in the climate. 


\section{Paleoclimatic record}

The Humedal La Estrella wetland has been functioning since at least the Mid-Holocene. It is clear that there is a low preservation potential in the system, as most of stratigraphic sections show the contact between wetland deposits and the Miocene tuff intercalation. Hence, older paleowetland deposits in the study area have been eroded. A simplified geologic cycle is proposed to describe the wetland evolution (Fig. 10). First, under increased rainfalls, vegetation cover becomes more abundant and the ground-water level permanently rises to the surface, while hydromorphic soils develop.

Vegetation cover stabilizes the landform preventing soil erosion and increasing sediment accumulation. Second, the wetland undergoes hydric stress due to longer periods of dry conditions and the vegetation cover simultaneously decreases. Water tables drop dramatically and soils progressively change towards gypsic and/or saline conditions. Third, as the water shortage continues, soils and wetland deposits become fragile. Runoff and aeolian processes gradually erode the wetland deposits until the surface the Miocene tuff substratum is exposed. Finally, the cycle restarts with an increase in precipitations. 


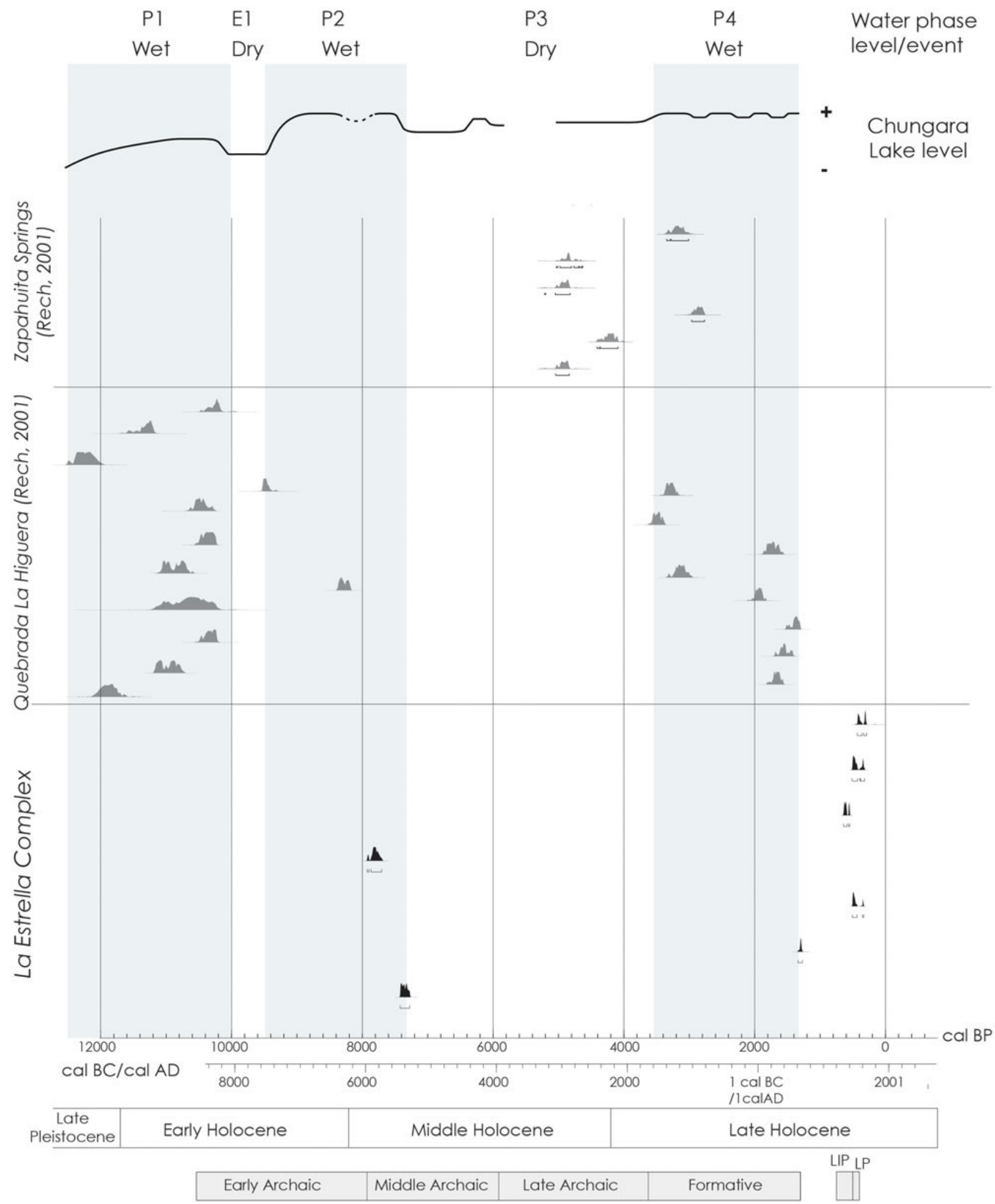

Figure 10. Radiocarbon ages from the paleosol of the Humedal La Estrella Complex, compared with local records from Rech (2001) and with the Chungara Lake record (Bao et al., 2015). Holocene limits according to Walker et al. (2012).

How are the six paleosol horizons from the Humedal La Estrella complex related to past variations in hydroclimate conditions? Available paleoclimate data indicate that the western Andean slope $\left(18-25^{\circ}\right)$ underwent variations in the regional hydrological cycle at centennial and millennial timescales over the last 18,000 yr (Latorre et al., 2002, 2003, 2006; Rech et al., 2002, 2003; Grosjean et al., 2005, 2007; Maldonado et al., 2005; Quade et al., 2008; Placzek et al., 2009; Gayo et al., 2012a, 2012b; Díaz et al., 2016; Sáez et al., 2016; de Porras et al., 2017; Pfeiffer et al., 2018). In this context, the record of paleosol 
formation within the wetland system appear to be discontinuous, identifying four episodes of hydroclimate anomalies at 7755-7300, 1270 (AD 680), 545 (AD 1400), and 400-300 cal yr BP (AD 1550-1650; Table 1).

Many paleoclimate records show evidence of widespread arid conditions in the region since $8500 \mathrm{cal}$ yr BP (Baied and Wheeler, 1993; Schwalb et al., 1999; Latorre et al., 2006; Moreno et al., 2007, 2009; Quade et al., 2008; Pueyo et al., 2011; Hernandez et al., 2013). This prolonged dry spell was interrupted by a brief but prominent wet interlude that sharply coincides with the chronology for the top of Unit $\mathrm{C}$ (7755-7300 cal yr BP). Either at the WA2b or WA4b section, the $\mathrm{H}$ horizon of the Unit C is covered by silty clayey sediments of Unit B (i.e., C horizon), suggesting that such episode of increased rainfalls ceased after 7300 cal yr BP. This wet-dry cycle in our paleowetland record is consistent either in chronology or direction with changes inferred at 9000-7000 cal yr BP from paleohydrological proxies from the high-elevation Chungara Lake (50 km north of our study site; Fig. 10; Moreno et al., 2007, 2009; Pueyo et al., 2011; Bao et al., 2015). Similarly, it correlates with slightly wetter conditions at $7330-6720$ cal yr BP recorded in rodent middens from the Río Salado basin $\left(22^{\circ} \mathrm{S}\right.$; Latorre et al., 2006). In comparison to paleowetlands located close to our system, the Mid-Holocene positive hydroclimate anomaly detected in the Humedal La Estrella does not match in timing with increased ground-water discharge events detected at Quebrada la Higuera and Zapahuira (Rech, 2001). Indeed, periods of increased rainfalls in these ground- water-fed wetlands are manifested during the Pleistocene-Holocene transition (13,800-10,200 cal yr BP), at the interval 5900-4800 cal yr BP, and then after $3000 \mathrm{cal}$ yr BP (Rech, 2001).

Our two radiocarbon ages on WA2b and WA4b sections define a maximum age for the Mid-Holocene wet phase recorded at Humedal La Estrella complex. This implies that our chronology for this event is limited and requires expansion to evaluate any relationship between our horizon $\mathrm{H}$ with other late Pleistocene paleowetland sequences described for the Atacama Desert (Rech, 2001; Rech et al., 2002, 2003; Quade et al., 2008). Due to the massive thickness of the $\mathrm{H}$ horizon $(>100 \mathrm{~cm})$, it is possible that this deposit may be paleoclimatically and chronologically related to the Unit B3 defined for wetland deposits dated at 12,700-9700 cal yr BP in other locations in the Atacama (18-25 ${ }^{\circ} \mathrm{S}$; Rech, 2001; Rech et al., 2002, 2003; Quade et al., 2008). In deposits preserved within Quebrada la Higuera, Rech (2001) identifies that the maximum age for the Unit B3 is around 10,200 cal yr BP, discarding a potentially "contaminated" youngest age of $9450 \mathrm{cal} \mathrm{yr} \mathrm{BP.} \mathrm{Considering} \mathrm{this} \mathrm{information,} \mathrm{the} \mathrm{minimum} \mathrm{age} \mathrm{for} \mathrm{Unit}$ $\mathrm{C}$ may be dated back to the latest Pleistocene, indicating the accumulation of organic horizon during the second stage (11,700-8500 cal yr BP) of the "Central Andean Pluvial Event" (CAPE), the most prominent wet interlude recorded regionally over the last 18,000 yr (Latorre et al., 2006; Quade et al., 2008; Placzek et al., 2009; Gayo et al., 2012a; Sáez et al., 2016; de Porras et al., 2017). The wet phase documented in the Humedal La Estrella complex between 7755-7300 cal yr BP is also present in Chungara Lake (Fig. 9). Hence, it is likely that the CAPE II stage extended beyond 8500 cal yr BP at $18^{\circ} \mathrm{S}$. Spatiotemporal differences in the expression of CAPE stages across the western Andean flank are commonly observed, reflecting the complex interaction of different climate regimes controlling the hydrological cycle over an area extending more than $1000 \mathrm{~km}$ (Quade et al., 2008; Placzek et al., 2009; Gayo et al., 2012a; Sáez et al., 2016; de Porras et al., 2017; Pfeiffer et al., 2018).

Alternatively, the accumulation of the $\mathrm{H}$ horizon may indicate brief but frequent wet pulses that followed the CAPE II stage and that the extreme thickness of the organic deposit in the Unit C is a result of high sedimentation rates. The majority of paleowetland deposits from the Atacama Desert do not present these conditions (Rech 2001; Rech et al., 2002, 2003; Quade et al., 2008), probably due to clear differences in the recharge mechanism accounting for ground-water-fed systems and our wetland sourced by direct rainfalls. 
Our record does not reproduce the wet phase detected regionally during the so-called Medieval Climate Anomaly (1050-680 cal yr BP; Maldonado et al., 2005; Gayo et al., 2012b; Morales et al., 2012; Mujica et al., 2014; Sáez et al., 2016). Still, Late Holocene paleosol formation events in our system are in overall agreement with other centennial and decadal scale positive hydroclimate anomalies. The paleosol formation in the Humedal La Estrella dated at 1270 cal yr BP coincides with a period of enhanced rainfalls (1400- 1200 cal yr BP) inferred from rodent middens collected along the Atacama between $18^{\circ}$ and $25^{\circ} \mathrm{S}$ (Latorre et al., 2002, 2003, 2006; Maldonado et al., 2005; Holmgren et al., 2008). Furthermore, it is practically synchronous with lacustrine high stands documented in the Chungara and Aricota basins at 1610-1300 cal yr BP (Placzek et al., 2001; Bao et al., 2015), whereas the accumulation of organic horizons at 545 and 400-300 cal yr BP correlate well with multidecadal wet pulses that interrupted the negative precipitation anomaly detected regionally during the Little Ice Age (Morales et al., 2012; Mujica et al., 2014).

The apparent discrepancy in the timing and duration of positive hydroclimate anomalies recorded in the Humedal La Estrella complex versus ground-water-sourced wetlands from the western Andean flank is not evident during the Late Holocene. Paleowetland deposits within canyons or springs suggest a concomitant rise in water tables around 2000-1300 and 800-400 cal yr BP (Rech, 2001, Rech et al., 2002, 2003; Nester et al., 2007; Gayo et al., 2012b; Sáez et al., 2016). This indicates that organic horizons from 1270 and 545-300 cal yr BP are coeval to Units D1 (2000- $1300 \mathrm{cal}$ yr BP) and D2 (800-400 cal yr BP), identified in sequences from the northern and central Atacama Desert (Rech 2001; Rech et al., 2002, 2003), respectively. This correlation needs to be to be evaluated, however, with further radiocarbon determinations, as it relies on a single date on sediments from the top of the thick organic horizon (Table 1, sample D-AMS 027602).

\section{Implications for regional human settlement}

A recent study on settlement patterns since the twelfth century AD in the Arica Precordillera identifies several villages that were established near to agricultural productive areas (Saintenoy et al., 2017). Furthermore, the authors emphasized a strong farming imprint around the three previously identified large agricultural localities (Muñoz Ovalle, 2005). Evidence of small settlements with 2 to 5 circular structures of less than $7 \mathrm{~m}$ in diameter were identified (Saintenoy et al., 2017), linked both to agricultural practices and livestock. Thus, the findings from the wetland partially portrays the settlement pattern in this area during the late pre-Hispanic period, specifically during the Late Intermediate period between the twelfth and the fifteenth centuries AD. Moreover, specific links exist with the available water resources from possible perched wetland areas, indicating a complementary seasonal relationship with the Tignamar River. Indeed, the four sectors present findings within areas that do not relate to rivers, but present favorable conditions to the development of perched wetland systems, similar to the results described in this article. Further studies are required to verify this hypothesis.

Although the settlements seem to correlate with the youngest wetland paleosols, the possibility that the correlation existed in a previous period of regional pre-Hispanic settlement should be considered. Evidence of previous settlement suggested by the recent discovery of occupations attributed to the Early (10,500-8500 years cal BP) and Late (6000-3700 years cal BP) phases of the Archaic period in a radius of 1-5 km around the wetland (Sepúlveda et al., 2017a). Several archaeological sites were identified surrounding the wetlands corresponding to shelters with and without rock art and openair camps. The evidence from these sites demonstrates not only a variety of daily activities but also different ways of occupying space (Sepúlveda et al., 2017a, b, 2018). It is likely that, in the wetland complex investigated in this study, more recent occupations have diminished the visibility of previous older ones and prevent their identification during surface surveys. Considering the Archaic evidence presented so far, however, 
it seems probable that hunter-gatherer groups have traveled through the sector as part of their mobility subsistence system, thus taking advantage of the resources available around these wetlands.

As noted previously, wetlands are attractive areas for the human settlement, especially in deserts areas. Nicholas (1998) stresses that wetlands played a significant role for hunter-gatherer groups because of their ecological characteristics. The presence of wetland-related vestiges from hunter gatherer groups provide useful information on diverse aspects such as mobility, population density, social stratification, and local cultural and economic diversity. In the Atacama Desert, multiple studies have revealed the importance of wetland areas for hunter-gatherers (e.g., Grosjean et al., 2005; Latorre et al., 2013, Núñez et al., 2013). Nonetheless, all these examples are related to wetlands connected to large water-fed systems, like rivers or springs outcropping at the base of Andean slopes or through fault systems. By contrast, ours study appears to be the first to investigate the possible role of ephemeral wetlands, i.e., unpredictable systems that are intermittently inundated with water may dry on an annual basis (Calhoun et al., 2017). In desert areas that lie on the transition between hyperarid desert and semiarid desert, such as the one in this study, this kind of wetland could have been a valuable resource for highly mobile groups such as hunter-gatherers. This study confirms the existence of wetland systems fed directly by rainfalls in the Atacama Desert, and it will be valuable to continue exploring this matter in the future.

\section{CONCLUSION}

We used geomorphological, pedostratigraphic, geochemical, and contemporary vegetation data to understand the formation of the Humedal La Estrella complex, a high-elevation (3300 m asl) wetland located in the Atacama Desert of northern Chile. The site is classified as a flat "perched" wetland based on topographic and hydrogeologic criteria. This type of wetland has not been previously documented in the Atacama Desert, thus this is a first description of its current functioning and also uses general knowledge to deepen the understanding of paleowetland deposits. Two main factors control the functioning of this wetland: (1) gain of water from direct precipitations; and (2) an impermeable layer corresponding to a Miocene tuff located close to the surface, which allows for the existence of local shallow ground water. The ground-water table recharges during the rainy season (November-March) and moves vertically towards the surface, enabling saturation near the surface of the soil.

The Humedal La Estrella complex consists of four wetland areas with a similar pedostratigraphic sequence, consisting of three units (Units A, B, and C) of paleowetland deposits which overlie a saprolith (i.e., altered and unaltered parts of the Miocene tuff). Evidence from all studied sections suggest that this paleowetland sequence spans the entire Holocene. Paleosol horizons are identified in Units B and C, which are considered to reflect periods of enhanced precipitations on a regional scale. Unit $\mathrm{C}$ corresponds to a thick H horizon, with the top layer dated from between 7755 and $7300 \mathrm{cal} \mathrm{yr} \mathrm{BP.} \mathrm{We} \mathrm{propose} \mathrm{two}$ alternative explanations for the this paleosol formation: (1) it was accumulated during the second stage of the CAPE II, which, in turn, extended beyond 8500 cal yr BP at $18^{\circ} \mathrm{S}$; or (2) it represents a brief pulse that followed the CAPE II, which is also replicated in the Chungara lacustrine records (Moreno et al., 2007, 2009; Pueyo et al., 2011; Bao et al., 2015) as well as in rodent-middens series from the Río Salado basin (Latorre et al., 2006). Unit B consists of several paleosols that are dated back to the Late Holocene. In general, these are consistent with wetter interludes recorded in other hydroclimate reconstructions for the Atacama Desert, specifically at ca. 1270, 545, and 410-300 cal yr BP. The synchronicity with other records for changes in hydroclimate conditions in the Atacama implies that paleosols preserved at the Humedal La Estrella represent feasible proxies for past variations in local and regional hydrological cycle.

Our results indicate that this wetland system played a pivotal role on local human settlement patterns since preHispanic times. Indeed, we verify that the area was occupied by pastoralist groups that 
established "estancias" between the twelfth and fifteenth centuries. Apparently, these small farms were related to the La Estrella wetland complex and/or to other equivalent and closer environment that developed as hydrological local budgets increased locally (i.e., amplified precipitations) providing valuable resources such as freshwater and fodder. Likely, this kind of system functioned during the Early and Mid-Holocene and, in turn, affected Archaic hunter-gatherer occupation patterns in highland and/or low elevation areas of the Atacama.

\section{ACKNOWLEDGMENTS}

This work was supported by the Chilean government projects FONDECYT 3150664, 1130808, 11150210, the Proyecto UTA-Mayor de Investigación Científica y Tecnológica 2017 8766-17, and the FB-0002-2014 to CAPES. EMG and RDH acknowledge the support of FONDAP 15110009 to (CR)2. We would additionally like to thank José Carcamo, Francisco Espinosa, Zaray Guerrero, Jorge Molina, and Ximena Power for providing assistance during fieldwork; Pilar Babot for assisting in the identification of phytoliths; Alicia Marticorena for assisting with the identification of plants; and Federico Luebert for providing critical bibliographic references.

\section{REFERENCES}

Aber, J.S., Pavri, F., Aber, S., 2012. Wetland Environments: A Global Perspective. John Wiley and Sons.

Aitchison, J., 1986. The Statistical Analysis of Compositional Data. Chapman and Hall, London.

Aitchison, J., Greenacre, M., 2002. Biplots of compositional data. Journal of the Royal Statistical Society: Series C (Applied Statistics) 51, 375-392.

Alley, R.B., Marotzke, J., Nordhaus, W.D., Overpeck, J.T., Peteet, D.M., Pielke, J.R., Pierrehumbert, R.A., et al., 2002.

Abrupt Climate Change: Inevitable Surprises. National Research Council, National Academy Press, Washington, DC.

Arroyo, M.K., Villagrán, C., Marticorena, C., Armesto, J.J., 1982. Flora y relaciones biogeograficas en los Andes del norte de Chile (18-19S). In: A. Veloso \& E. Bustos (Eds.), El ambiente natural y las poblaciones humanas de los Andes del Norte Grande de Chile (Arica, Lat. 1828 S). UNESCO, Montevideo, pp. 71-92.

Arroyo, M.T.K., Squeo, F.A., Armesto, J.J., Villagran, C., 1988. Effects of aridity on plant diversity in the northern Chilean Andes: results of a natural experiment. Annals of the Missouri Botanical Garden $75,55-78$.

Ayala, Cabrera y Asociados 1tda., 2003. Diagnóstico actual del riego y drenaje en Chile y su proyección. Diagnóstico del riego y drenaje en la I región. Final Report. Comision Nacional de Riego, Santiago.

Babel, U., 1975. Micromorphology of soil organic matter. Soil Components 1, 369-473.

Baied, C.A., Wheeler, J.C., 1993. Evolution of high Andean puna ecosystems: environment, climate, and culture change over the last 12,000 years in the Central Andes. Mountain Research and Development, 145-156.

Bao, R., Hernández, A., Sáez, A., Giralt, S., Prego, R., Pueyo, J.J., Moreno, A., Valero-Garcés, B.L., 2015. Climatic and lacustrine morphometric controls of diatom paleoproductivity in a tropical Andean lake. Quaternary Science Reviews 129, 96-110.

Bindler, R., 2006. Mired in the past - looking to the future: Geochemistry of peat and the analysis of past environmental changes. Global And Planetary Change, Peatlands: Records of Global Environmental Changes 53, 209-221.

Birkeland, P.W., 1984. Soils and Geomorphology. Oxford University Press, New York. 
Blazejewski, G.A., Stolt, M.H., Gold, A.J., Groffman, P.M., 2005. Macro- and micromorphology of subsurface carbon in riparian zone soils. Soil Science Society of America Journal 69, 1320.

Buttolph, L., 1998. Rangeland Dynamics and Pastoral Development in the High Andes: The Camelid Herders of Cosapa, Bolivia. PhD dissertation, Utah State University, Logan, USA.

Calhoun, A.J.K., Mushet, D.M.,Bell, K.P.,Boix, D., Fitzsimons, J.A., Isselin-Nondedeu, F., 2017. Temporary wetlands: challenges and solutions to conserving a 'disappearing' ecosystem. Biological Conservation, Small Natural Features 211, 3-11.

Casby-Horton, S., Herrero, J., Rolong, N.A., 2015. Gypsum soils - their morphology, classification, function, and landscapes. In: Sparks, D.L. (Ed.), Advances in Agronomy. Academic Press, pp. 231290.

Comas, M., Thió-Henestrosa, S., 2011. CoDaPack 2.0: a stand-alone, multi-platformcompositional software. CoDaWork'11, Girona, Spain.

de Porras, M.E., Maldonado, A., Pol-Holz, R.D., Latorre, C., Betancourt, J.L., 2017. Late Quaternaryenvironmental dynamics in the Atacama Desert reconstructed from rodent midden pollen records. Journal of Quaternary Science 32, 665-684.

DGA (Dirección General de Aguas), 1986. Mapa hidrogeológico de Chile, escala 1:2.500.000. Texto explicativo. Ministerio de Obras Publicas (MOP), Santiago.

Díaz, F.P., Frugone, M., Gutiérrez, R.A., Latorre, C., 2016. Nitrogen cycling in an extreme hyperarid environment inferred from $\delta 15 \mathrm{~N}$ analyses of plants, soils and herbivore diet. Scientific Reports 6 , 22226.

Dubroeucq, D., Geissert, D., Quantin, P., 1998. Weathering and soil forming processes under semi-arid conditions in two Mexican volcanic ash soils. Geoderma 86, 99-122.

Dudognon, C., Sepúlveda, M., 2016. Rock art of the upper Lluta valley, northernmost of Chile (South Central Andes): a visual approach to socio-economic changes between Archaic and Formative periods (6,000-1,500 years BP). Quaternary International 491, 136-145.

Flewett, S., Saintenoy, T., Sepúlveda, M., Mosso, E.F., Robles, C., Vega, K., Gutierrez, S., et al., 2016. Micro x-ray fluorescence study of late pre-Hispanic ceramics from the western slopes of the south central Andes region in the Arica y Parinacota region, Chile: a new methodological approach. Applied Spectroscopy 70, 1759-1769.

Food and Agriculture Organization-World Reference Base (FAO-WRB), International Union of Soil Sciences (IUSS) Working Group, 2014. World Reference Base for Soil

Resources 2014. International soil classification system for naming soils and creating legends for soil maps. World Soil Resources Reports No. 106. Food and Agriculture Organization of the United Nations, Rome.

Garcia, M., Gardeweg, M., Clavero, J., Hérail, G., 2004. Hoja Arica, Región de Tarapacá. Servicio Nacional de Geología y Minería, Carta Geológica de Chile, Serie Geología Básica, No. 84. SERNAGEOMIN,Santiago.

Garreaud,R.,Vuille,M.,Clement,A.C.,2003. The climate of the Altiplano: observed current conditions and mechanisms of past changes. Palaeogeography, Palaeoclimatology, Palaeoecology 194, 5-22.

Gayo, E.M., Latorre, C., Jordan, T.E., Nester, P.L., Estay, S.A., Ojeda, K.F., Santoro, C.M., 2012a. Late Quaternary hydrological and ecological changes in the hyperarid core of the northern Atacama Desert ( $\left.21^{\circ} \mathrm{S}\right)$. Earth-Science Reviews 113, 120-140.

Gayo, E.M., Latorre, C., Santoro, C.M., Maldonado, A., de Pol-Holz, R., 2012b. Hydroclimate variability in the lowelevation Atacama Desert over the last $2500 \mathrm{yr}$. Climate of the Past 8, 287-306.

Grosjean, M., Núñez, L., Cartajena, I., 2005. Palaeoindian occupation of the Atacama Desert, northern Chile. Journal of Quaternary Science 20, 643-653. 
Grosjean, M., Santoro, C.M., Thompson, L.G., Núñez, L., Standen, V.G., 2007. Mid-Holocene climate and culture change in the South Central Andes. In: Anderson, D.G., Maasch, K.A., Sandweiss, D.H. (Eds.), Climate Change and Cultural Dynamics. Academic Press, San Diego, pp. 51-115.

Guilloré, P., 1980. Méthode de fabrication mécanique et en série des lames minces. Institut National d'Agronomie Paris-Grignon, Département des Sols, Paris.

Gustavsson, M., Kolstrup, E., Seijmonsbergen, A.C., 2006. A new symbol-and-GIS based detailed geomorphological mapping system: Renewal of a scientific discipline for understanding landscape development. Geomorphology 77, 90-111.

Hernández, A., Bao, R., Giralt, S., Sáez, A., Leng, M.J., Barker, P.A., Kendrick, C.P., Sloane, H.J., 2013. Climate, catchment runoff and limnological drivers of carbon and oxygen isotope composition of diatom frustules from the central Andean Altiplano during the Lateglacial and Early Holocene. Quaternary Science Reviews 66, 64-73.

Herrera, C., Custodio, E., Chong, G., Lambán, L.J., Riquelme, R., Wilke, H., Jódar, J., et al., 2016. Groundwater flow in a closed basin with a saline shallow lake in a volcanic area: Laguna Tuyajto, northern Chilean Altiplano of the Andes. Science of the Total Environment 541, 303-318.

Holmgren, C.A., Rosello, E., Latorre, C., Betancourt, J.L., 2008. Late-Holocene fossil rodent middens from the Arica region of northernmost Chile. Journal of Arid Environments 72, 677-686.

Houston, J., 2006. Variability of precipitation in the Atacama Desert: its causes and hydrological impact. International Journal of Climatology 26, 2181-2198.

Houston, J., Hartley, A.J., 2003. The central Andean west-slope rainshadow and its potential contribution to the origin of hyperaridity in the Atacama Desert. International Journal of Climatology 23, 1453-1464.

Junk, W.J., An, S., Finlayson, C.M., Gopal, B., Kvet, J.,`' Mitchell, S.A., Mitsch, W.J., Robarts, R.D., 2013. Current state of knowledge regarding the world's wetlands and their future under global climate change: a synthesis. Aquatic Sciences 75, 151-167.

Kent, M., 2011. Vegetation Description and Data Analysis: A Practical Approach. John Wiley and Sons, Chichester, West Sussex, UK.

Latorre, C., Betancourt, J.L., Arroyo, M.T.K., 2006. Late Quaternary vegetation and climate history of a perennial river canyon in the Río Salado basin $\left(22^{\circ} \mathrm{S}\right)$ of northern Chile. Quaternary Research 65 , 450-466.

Latorre, C., Betancourt, J.L., Rylander, K.A., Quade, J., 2002. Vegetation invasions into absolute desert: a $45000 \mathrm{yr}$ rodent midden record from the Calama-Salar de Atacama basins, northern Chile (lat $22^{\circ}$ $\left.24^{\circ} \mathrm{S}\right)$. Geological Society of America Bulletin 114, 349-366.

Latorre, C., Betancourt, J.L., Rylander, K.A., Quade, J., Matthei, O., 2003. A vegetation history from the arid prepuna of northern Chile $\left(22-23^{\circ} \mathrm{S}\right)$ over the last 13500 years. Palaeogeography, Palaeoclimatology, Palaeoecology 194, 223-246.

Maldonado, A., Betancourt, J.L., Latorre, C., Villagran, C., 2005. Pollen analyses from a 50 000-yr rodent midden series in the southern Atacama Desert (2530' S). Journal of Quaternary Science 20, 493-507.

Martín-Fernández, J., Barceló-Vidal, C., Pawlowsky-Glahn, V., 2003. Dealing with zeros and missing values in compositional data sets using nonparametric imputation. Mathematical Geology 35, 253278.

Melly, B.L., Schael, D.M., Gama, P.T., 2017. Perched wetlands: an explanation to wetland formation in semi-arid areas. Journal of Arid Environments 141, 34-39.

Morales, M.S., Christie, D.A., Villalba, R., Argollo, J., Pacajes, J., Silva, J.S., Alvarez, C.A., Llancabure, J.C., Soliz Gamboa, C.C., 2012. Precipitation changes in the South American Altiplano since 1300 AD reconstructed by tree-rings. Climate of the Past 8, 653-666. 
Moreno, A., Giralt, S., Valero-Garcés, B., Sáez, A., Bao, R., Prego, R., Pueyo, J.J., González-Sampériz, P., Taberner, C., 2007. A $14 \mathrm{kyr}$ record of the tropical Andes: The Lago Chungará sequence $\left(18^{\circ} \mathrm{S}\right.$, northern Chilean Altiplano). Quaternary International 161, 4-21.

Moreno, A., Santoro, C.M., Latorre, C., 2009. Climate change and human occupation in the northernmost Chilean Altiplano over the last ca. 11500 cal. a BP. Journal of Quaternary Science 24, 373-382.

Mortimer, C., Saric, N., 1972. Landform evolution in the coastal region of Tarapacá Province, Chile. Revue de géomorphologie dynamique 21, 162-170.

Mujica, M.I., Latorre, C., Maldonado, A., González-Silvestre, L., Pinto, R., de Pol-Holz, R., Santoro, C.M., 2014. Late Quaternary climate change, relict populations and present-day refugia in the northern Atacama Desert: a case study from Quebrada La Higuera (18 $\left.{ }^{\circ} \mathrm{S}\right)$. Journal of Biogeography 42, 76-88.

Muñoz, I., Briones, L., 1996. Poblados, rutas y arte rupestre precolombinos de Arica: descripción y análisis de sistema de organización. Chungará 28, 47-84.

Muñoz Ovalle, I., 2005. Espacio social y áreas de actividad en asentamientos agrícolas prehispánicos tardíos en la sierra de Arica. Bulletin de l'Institut Français d'Études Andines 34, 321-355.

Naranjo, J.A., Paskoff, R., 1985. Evolución cenozoica del piedemonte andino en la Pampa del Tamarugal, norte de Chile (18-21 S). In: Congreso Geológico Chileno. Publisher, Antofagasta, Chile, pp. 149-165.

Navarro, G., 1993. Vegetación de Bolivia: el Altiplano meridional. Rivasgodaya 7, 69-98.

Nester, P.L., Gayó, E., Latorre, C., Jordan, T.E., Blanco, N., 2007. Perennial stream discharge in the hyperarid Atacama Desert of northern Chile during the latest Pleistocene. Proceedings of the National Academy of Sciences of the United States of America 104, 19724-19729.

Nicholas, G.P., 1998. Wetlands and hunter-gatherers: a global perspective. Current Anthropology 39, 720-731.

Niemeyer, H., 1989. El Escenario geográfico. In: Jorge Hidalgo L., Culturas de Chile 1 Prehistoria: Desde Sus Orígenes Hasta Los Albores de La Conquista. Andrés Bello, Santiago, pp. 1-12.

Núñez, L., Cartajena, I., Grosjean, M., 2013. Archaeological silence and ecorefuges: arid events in the Puna of Atacama during the Middle Holocene. Quaternary International 307, 5-13.

Osorio, D., Steele, J., Sepúlveda, M., Gayo, E.M., Capriles, J.M., Herrera, K., Ugalde, P., De Pol-Holz, R., Latorre, C., Santoro, C.M., 2017. The Dry Puna as an ecological megapatch and the peopling of South America: technology, mobility, and the development of a late Pleistocene/early Holocene Andean huntergatherer tradition in northern Chile. Quaternary International 461, 41-53.

Paskoff, R., 1979. Sobre la Evolución Geomorfológica del gran acantilado costero del Norte Grande de Chile. Norte Grande 6, 7-22.

Pfeiffer, M., Latorre, C., Santoro, C.M., Gayo, E.M., Rojas, R., Carrevedo, M.L., McRostie, V.B., et al., 2018. Chronology, stratigraphy and hydrological modelling of extensive wetlands and paleolakes in the hyperarid core of the Atacama Desert during the late quaternary. Quaternary Science Reviews 197, 224-245.

Pigati, J.S., Rech, J.A., Quade, J., Bright, J., 2014. Desert wetlands in the geologic record. Earth-Science Reviews 132, 67-81.

Placzek, C., Quade, J., Betancourt, J.L., 2001. Holocene lake-level fluctuations of Lake Aricota, southern Peru. Quaternary Research 56, 181-190.

Placzek, C., Quade, J., Betancourt, J.L., Patchett, P.J., Rech, J.A., Latorre, C., Matmon, A., Holmgren, C., English, N.B., 2009. Climate in the dry central Andes over geologic, millennial, and interannual timescales. Annals of the Missouri Botanical Garden 96, 386-397.

Poch, R.M., Artieda, O., Herrero, J., Lebedeva-Verba, M., 2010. 
Gypsic features. In: Stoops, G., Marcelino, V., Mees, F. (Eds.), Interpretation of Micromorphological Features of Soils and Regoliths. Elsevier, Amsterdam, pp. 195-216.

Porta, J., Herrero, J., 1990. Micromorphology and Genesis of Soils Enriched with Gypsum. In: Lowell A. Doublas, Soil MicroMorphology: A Basic and Applied Science. Proceedings of the VIIIth International Working Meeting of Soil Micromorphology. Elsevier, San Antonio, Texas, pp. 321-339.

Pueyo, J.J., Sáez, A., Giralt, S., Valero-Garcés, B.L., Moreno, A., Bao, R., Schwalb, A., Herrera, C., Klosowska, B., Taberner, C., 2011. Carbonate and organic matter sedimentation and isotopic signatures in Lake Chungará, Chilean Altiplano, during the last 12.3kyr. Palaeogeography, Palaeoclimatology, Palaeoecology 307, 339-355.

Qi, J., Chehbouni, A., Huete, A.R., Kerr, Y.H., Sorooshian, S., 1994. A modified soil adjusted vegetation index. Remote Sensing of Environment 48, 119-126.

Quade, J., Rech, J.A., Betancourt, J.L., Latorre, C., Quade, B., Rylander, K.A., Fisher, T., 2008. Paleowetlands and regional climate change in the central Atacama Desert, northern Chile. Quaternary Research 69, 343-360.

Rech, J.A., 2001. Late Quaternary Paleohydrology and Surficial Processes of the Atacama Desert, Chile: evidence from Wetland Deposits and Stable Isotopes of Soil Salts. PhD dissertation, University of Arizona, Tucson.

Rech, J.A., Pigati, J.S., Quade, J., Betancourt, J.L., 2003. Re-evaluation of mid-Holocene deposits at Quebrada Puripica, northern Chile. Palaeogeography, Palaeoclimatology, Palaeoecology 194, 207 222.

Rech, J.A., Quade, J., Betancourt, J.L., 2002. Late Quaternary paleohydrology of the central Atacama Desert (lat $22^{\circ}-24^{\circ} \mathrm{S}$ ), Chile. Geological Society of America Bulletin 114, 334-348.

Ruthsatz, B., 2012. Vegetación y ecología de los bofedales altoandinos de Bolivia. Phytocoenologia 42, 133-179.

Sáez, A., Godfrey, L.V., Herrera, C., Chong, G., Pueyo, J.J., 2016. Timing of wet episodes in Atacama Desert over the last $15 \mathrm{ka}$ : the groundwater discharge deposits (GWD) from Domeyko Range at $25^{\circ} \mathrm{S}$. Quaternary Science Reviews 145, 82-93.

Saintenoy,T.,Ajata,R.,Romero,A.L.,Sepulveda,M.,2017. Arqueología del territorio aldeano prehispánico tardío en los altos de Arica: aportes de la fotointerpretación satelital para el estudio regional de la cuenca alta de Azapa. Estudios Atacameños 54, 85-110.

Santoro, C., Osorio, D., Ugalde, P., Sepúlveda, M., Cartajena, I., Standen, V., Gayó, E., Maldonado, A., et al., 2016. Cazadores, recolectores y pescadores arcaicos del Desierto de Atacama, entre el Pacífico y los Andes, Norte de Chile (ca. 10.000- 3.700 años a.p.). In: Falabella, F., Sanhueza, L., Uribe, M., Aldunate, C., Hidalgo, J. (Eds.), Prehistoria en Chile: Desde sus primeros habitantes hasta los Incas. Editorial Universitaria, Santiago de Chile, pp. 117-180.

Scasso, R., Limarino, O., 1997. Petrología y Diagénesis de rocas clásticas. Publicación Especial no 1. Asociación Argentina de Sedimentología, Buenos Aires.

Schittek, K., Forbriger, M., Mächtle, B., Schäbitz, F., Wennrich, V., Reindel, M., Eitel, B., 2015. Holocene environmental changes in the highlands of the southern Peruvian Andes $\left(14^{\circ} \mathrm{S}\right)$ and their impact on pre-Columbian cultures. Climate of the Past 11, 27-44.

Schwalb, A., Burns, S.J., Kelts, K., 1999. Holocene environments from stable isotope stratigraphy of ostracods and authigenic carbonate in Chilean Altiplano Lakes. Palaeogeography, Palaeoclimatology, Palaeoecology 148, 153-168.

Sepúlveda, M., Cornejo, L., Osorio, D., Uribe, M., Llanos, C., 2018. Cazadores-recolectores en tiempos formativos. Trayectoria histórica local en la precordilleradel extremo norte de Chile. Chungara 50, $29-50$. 
Sepúlveda, M., Cornejo, L., Osorio, D., Sitzia, L., Saintenoy, T., Espinoza, F., 2017a. North/South Archaic Mobility in Dry Puna: Hunter-Gatherers from Upper Azapa Valley Basin, Northern Chile. Paper presented at the 82th Annual Meeting of the Society for American Archaeology, Vancouver, BC, Canada. Sepúlveda, M., Saintenoy, T., Cornejo, L., Dudognon, C., Espinoza, F., Guerrero-Bueno, Z., Cerrillo-Cuenca, E., 2017b.

Rock art painting and territoriality in the precordillera of northernmost Chile (South-Central Andes). Archeological and spatial approaches to the Naturalistic Tradition. Quaternary International. http://dx.doi.org/10.1016/j.quaint.2017.02.005.

Sitzia, L., Bertran, P., Sima, A., Chery, P., Queffelec, A., Rousseau, D.-D., 2017. Dynamics and sources of last glacial aeolian deposition in southwest France derived from dune patterns, grain-size gradients and geochemistry, and reconstruction of efficient wind directions. Quaternary Science Reviews 170, 250-268.

Smyth, R.C., Sharp, J.M., Jr., 2006. The hydrology of tuffs. In: EDITORS, Tuffs-Their Properties, Uses, Hydrology, and Resources. Special Paper 408. The Geological Society of America, CITY, pp. 91-112.

Squeo, F.A., Warner, B.G., Aravena, R., Espinoza, D., 2006. Bofedales: high altitude peatlands of the central Andes. Revista Chilena de Historia Natural 79, 245-255.

Stolt, M.H., Lindbo, D.L., 2010. 17 - Soil Organic Matter. In: Stoops, G., Marcelino, V., Mees, F., Interpretation of Micromorphological Features of Soils and Regoliths. Elsevier, Amsterdam, pp. 369396.

Stoops, G., 2003. Guidelines foranalysis and description of soil and regolith thin sections. Vepraskas, M.J. (Ed.), Soil Science Society of America, Madison, USA.

Stuiver, M., Reimer, P.J., Reimer, R.W., 2018, CALIB 7.1

(accessed October 30, 2018). http://calib.org.

Teiller, S., 1998. Flora y vegetación alto-andina del área de Collaguasi-Salar de Coposa, Andes del norte de Chile. Revista Chilena de Historia Natural 71, 313-329.

Tooth, S., McCarthy, T.S., 2007. Wetlands in drylands: geomorphological and sedimentological characteristics, with emphasis on examples from southern Africa. Progress in Physical Geography 31, 3-41.

Tosdal, R.M., Clark, A.H., Farrar, E., 1984. Cenozoic polyphase landscape and tectonic evolution of the Cordillera Occidental, southernmost Peru. Geological Society of America Bulletin 95, 1318-1332.

Townley, L.R., 1998. Shallow groundwater systems. In: Dillon, P., Simmers, I. (Eds.), Shallow Groundwater Systems: IAH International Contribution to Hydrogeology. International Contributions to Hydrogeology 18. A.A. Balkema, Rotterdam, pp. 3-11.

Vandergoes, M.J., Newnham, R.M., Preusser, F., Hendy, C.H., Lowell, T.V., Fitzsimons, S.J., Hogg, A.G., Kasper, H.U., Schlüchter, C., 2005. Regional insolation forcing of late Quaternary climate change in the Southern Hemisphere. Nature 436, 242-245.

Vaniman, D., 2006. Tuff mineralogy. In: Heicken, G., Tuffs - Their Properties, Uses, Hydrology, and Resources. Special Paper 408. Geological Society of America, Penrose, pp. 91-112.

Vepraskas, M.J., Faulkner, S.P., 2000. Redox Chemistry of hydric soils. In: Richardson, J.L., Vepraskas, M.J. (Eds.), Wetland Soils Genesis, Hydrology, Landscapes, and Classification. CRC PRESS, Boca Raton, pp. 85-107.

Verdin, J. P. (1996) Remote sensing of ephemeral water bodies in westernNiger.InternationalJournalof RemoteSensing17,733-48.

Villagrán, C., Armesto, J.J., Arroyo, M.T.K., 1981. Vegetation in a high Andean transect between Turi and Cerro León in Northern Chile. Vegetatio 48, 3-16. 
Villagrán, C., Kalin Arroyo, M.T., Marticorena, C., 1983. Efectos de la desertización en la distribución de la flora andina de Chile. Revista Chilena de Historia Natural 137-157.

Vleeschouwer, F.D., Vanneste, H., Mauquoy, D., Piotrowska, N., Torrejón, F., Roland, T., Stein, A., Roux, G.L., 2014. Emissions from Pre-Hispanic metallurgy in the South American atmosphere.

PLoS ONE 9, e111315.

von Eynatten, H., Barceló-Vidal, C., Pawlowsky-Glahn, V., 2003. Modelling compositional change: the example of chemical weathering of granitoid rocks. Mathematical Geology 35, 231-251.

Vuille,M.,Ammann,C.,1997. Regional Snowfall Patterns in the High, Arid Andes. Climatic Change at High Elevation Sites 36, 181-191.

Vuille, M., Keimig, F., 2004. Interannual variability of summertime convective cloudiness and precipitation in the Central Andes derived from ISCCP-B3 data. Journal of Climate 17, 3334-3348.

Walker, M.J.C., Berkelhammer, M., Björck, S., Cwynar, L.C., Fisher, D.A., Long, A.J., Lowe, J.J., Newnham, R.M., Rasmussen, S.O., Weiss, H., 2012. Formal subdivision of the Holocene Series/Epoch: a Discussion Paper by a Working Group of INTIMATE (Integration of ice-core, marine and terrestrial records) and the Subcommission on Quaternary Stratigraphy (International Commission on Stratigraphy). Journal of Quaternary Science 27, 649-659.

Witham, C.S., Oppenheimer, C., Horwell, C.J., 2005. Volcanic ash leachates: a review and recommendations for sampling methods. Journal of Volcanology and Geothermal Research 141, 299 326.

Yokota, S., Iwamatsu, A., 2000. Weathering distribution in a steep slope of soft pyroclastic rocks as an indicator of slope instability. Engineering Geology 55, 57-68.

Zhou, J., Lau, K.-M., 1998. Does a Monsoon Climate Exist over South America? Journal of Climate 11, $1020-1040$.

Zuloaga, F.O., Morrone, O., Belgrano, M., 2008. Catálogo de las Plantas Vasculares del Cono Sur. Monographs in Systematic Botany 107. Missouri Botanical Garden Press, St. Louis. 


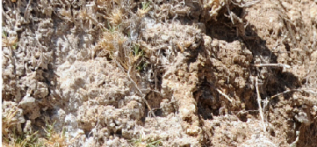

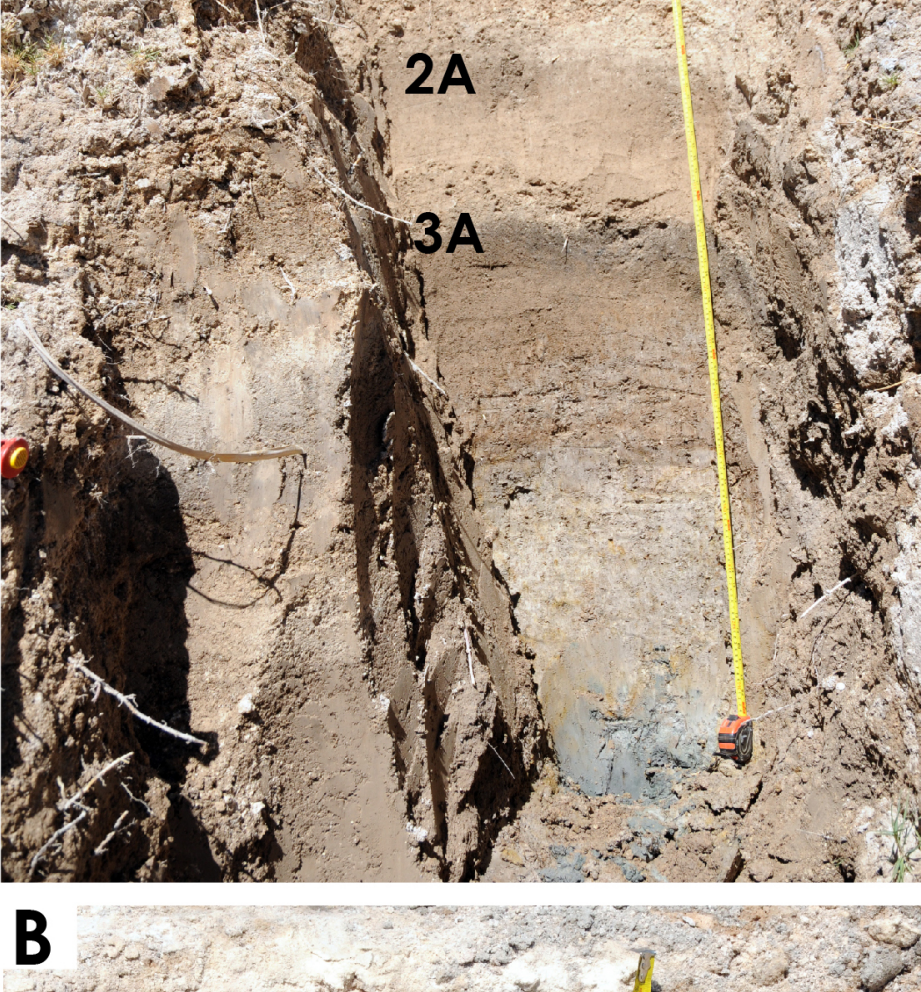

B

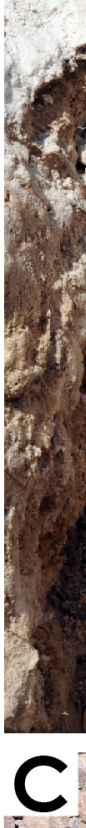

C

$$
\text { Huaylas Eormation }
$$

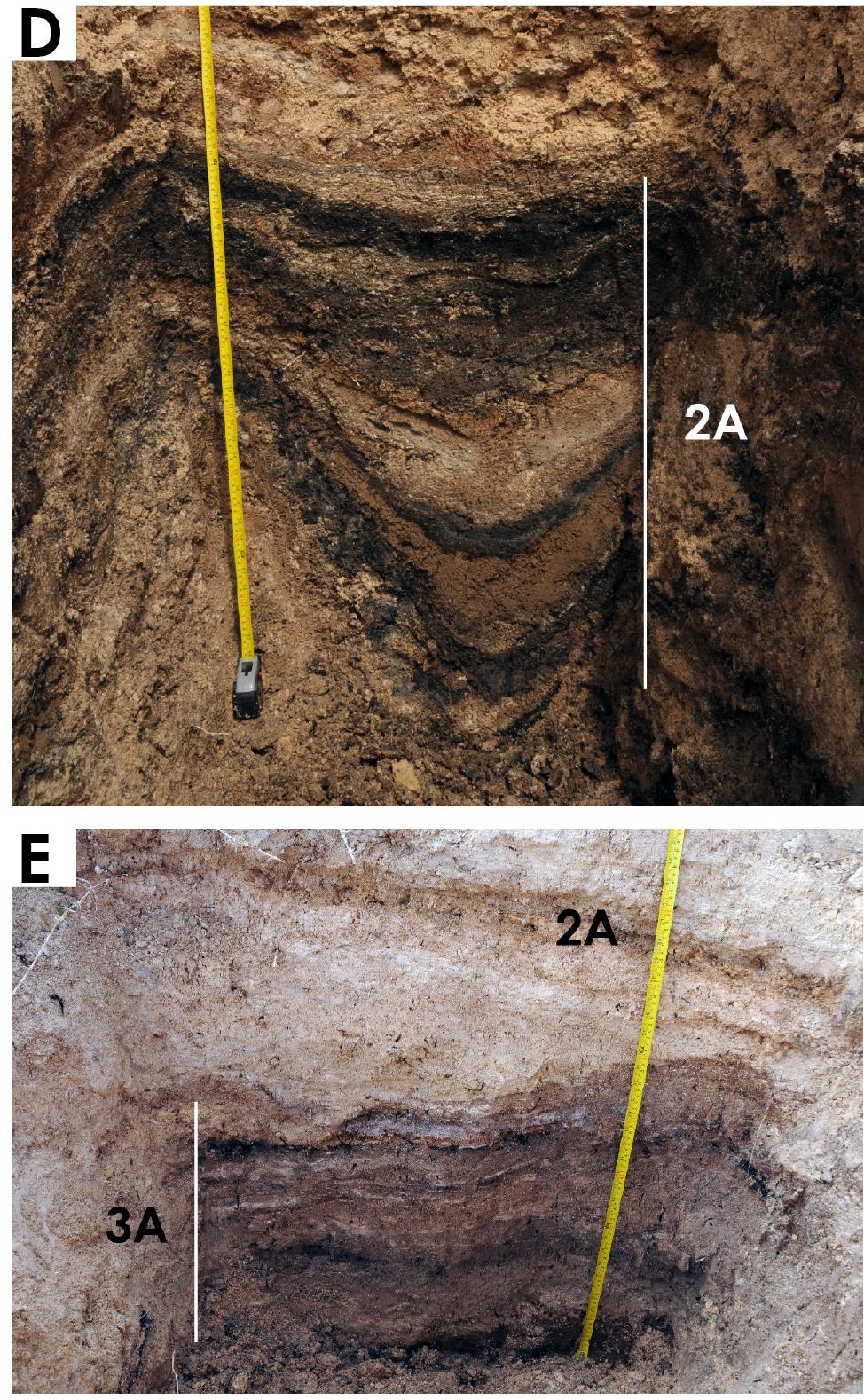

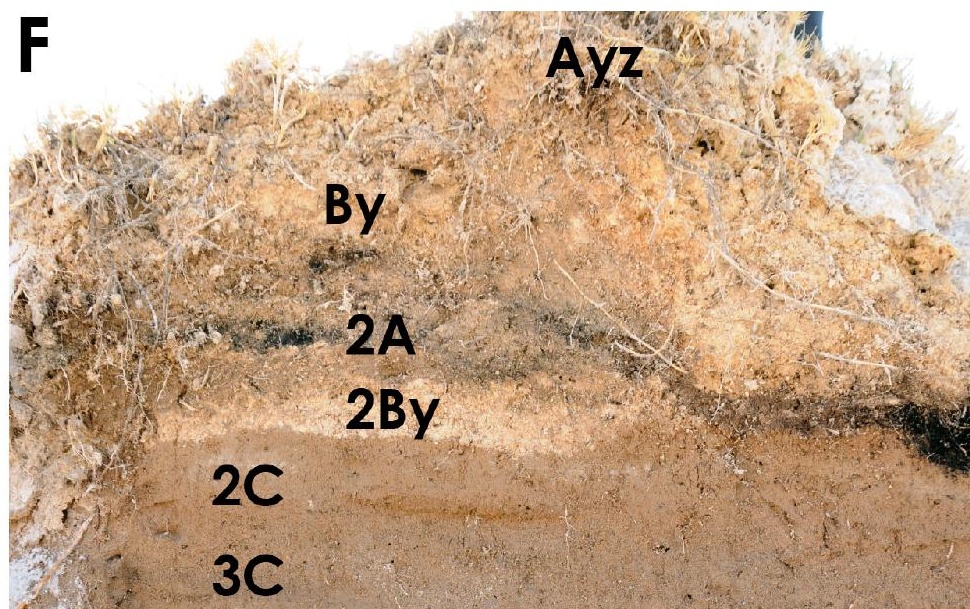

$4 \mathrm{Cg}$
$2 A$

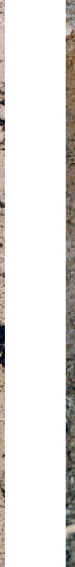

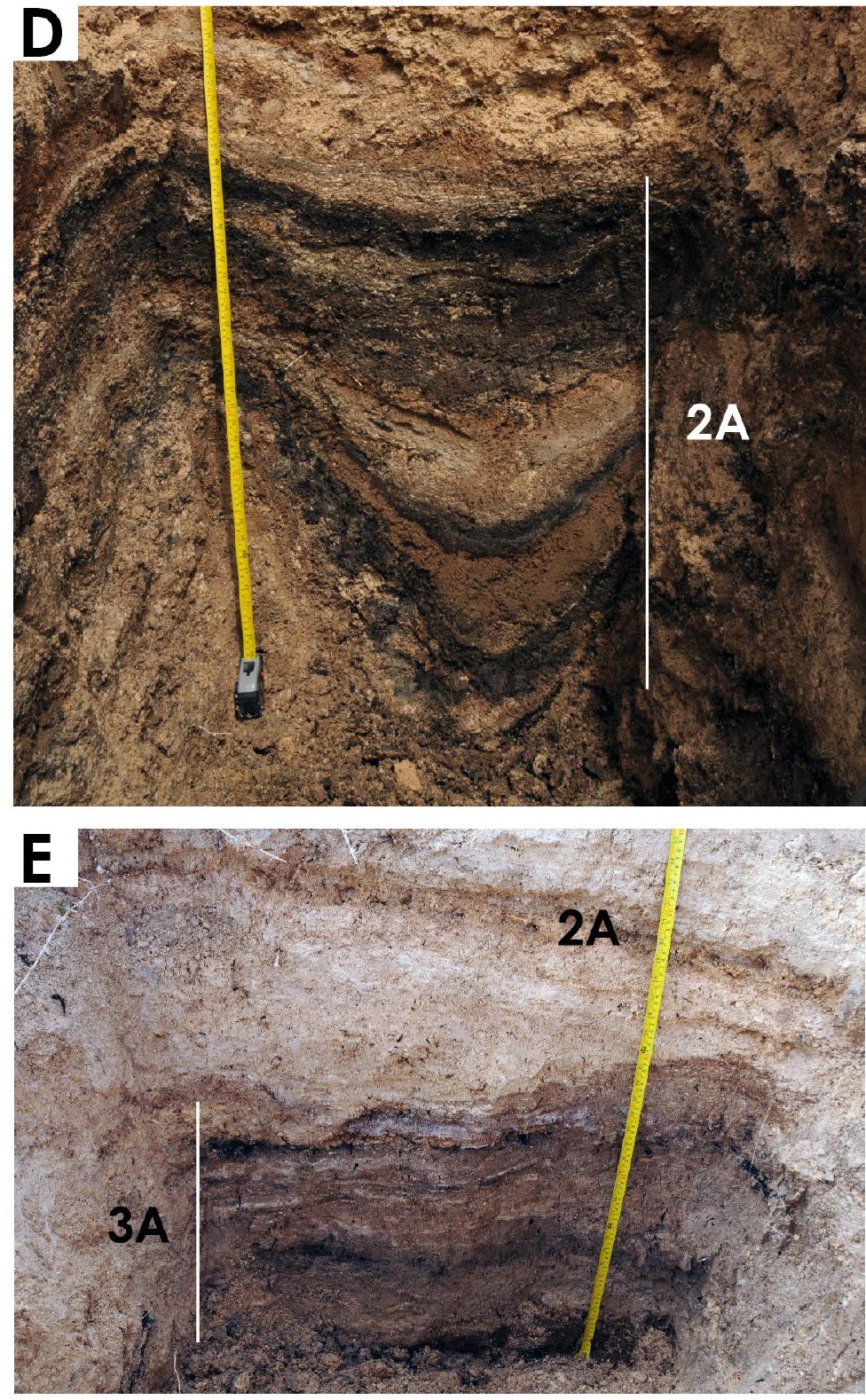




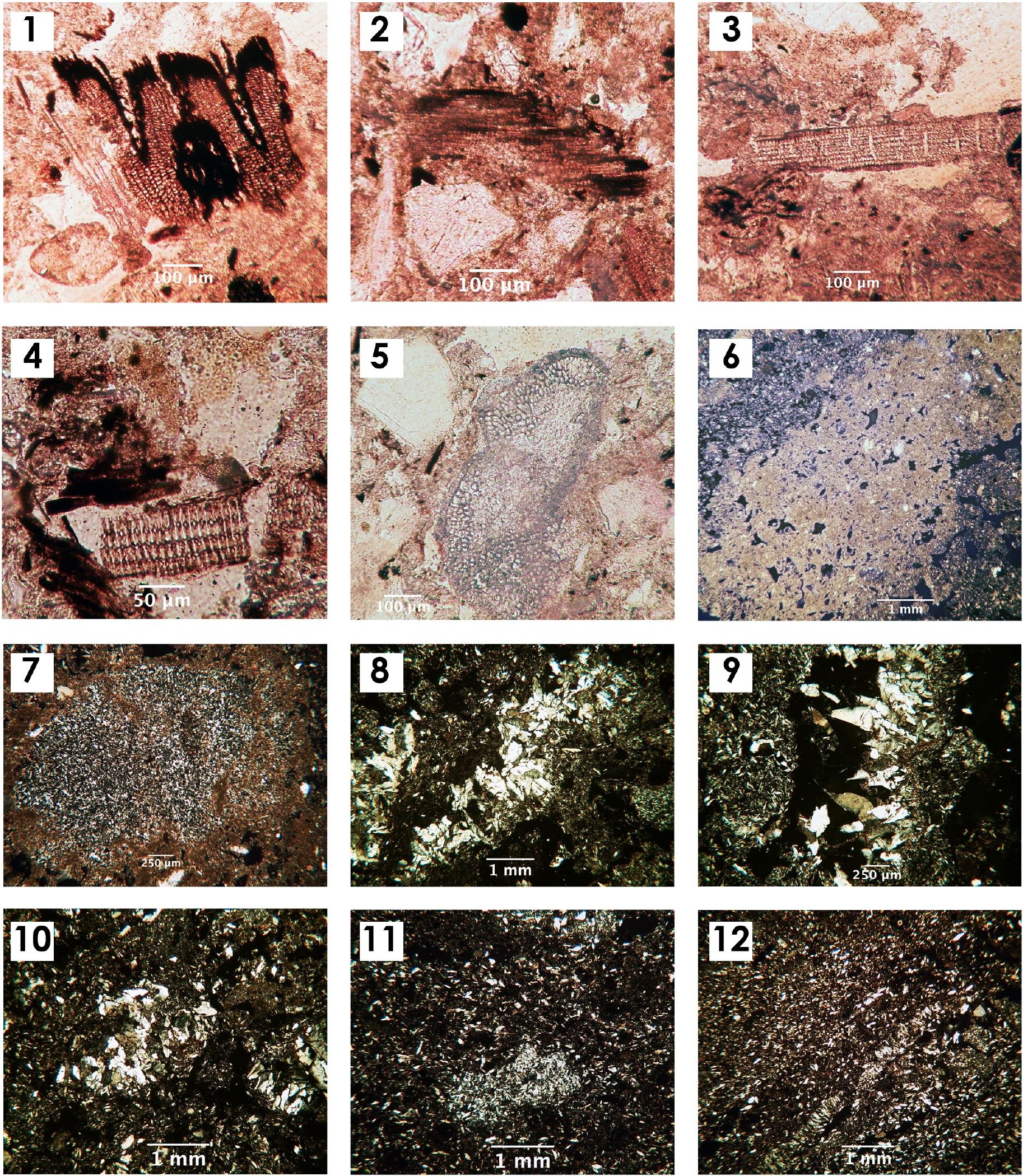


Profile SP1 . Thin section M1 - M6

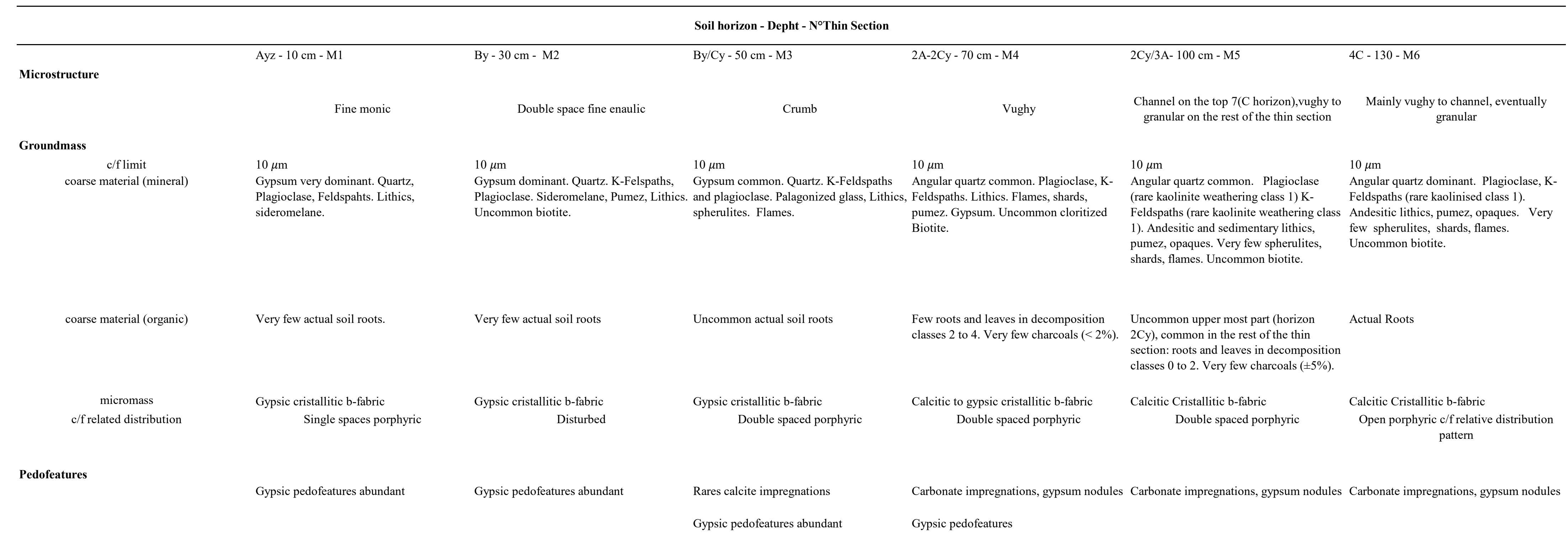




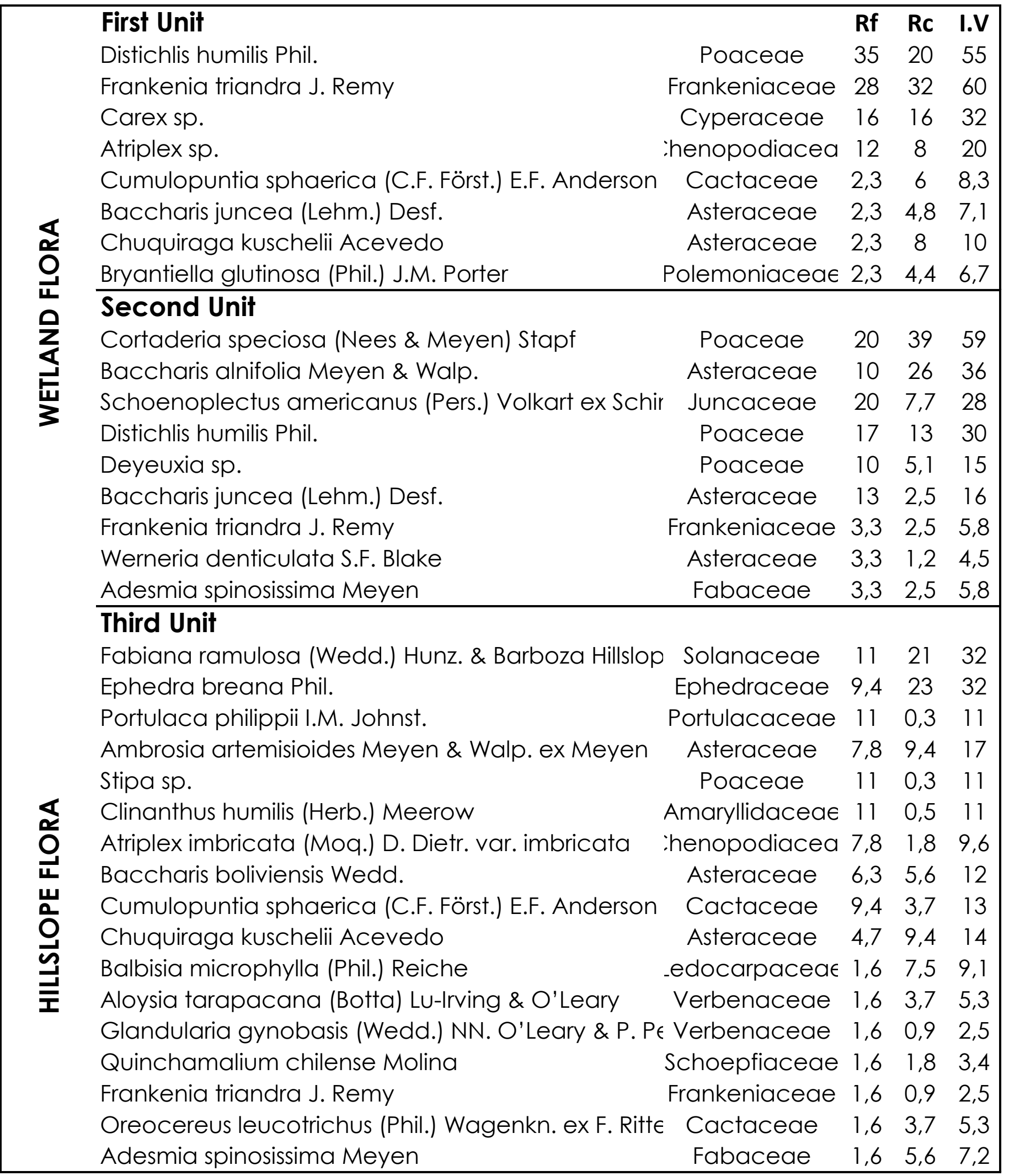




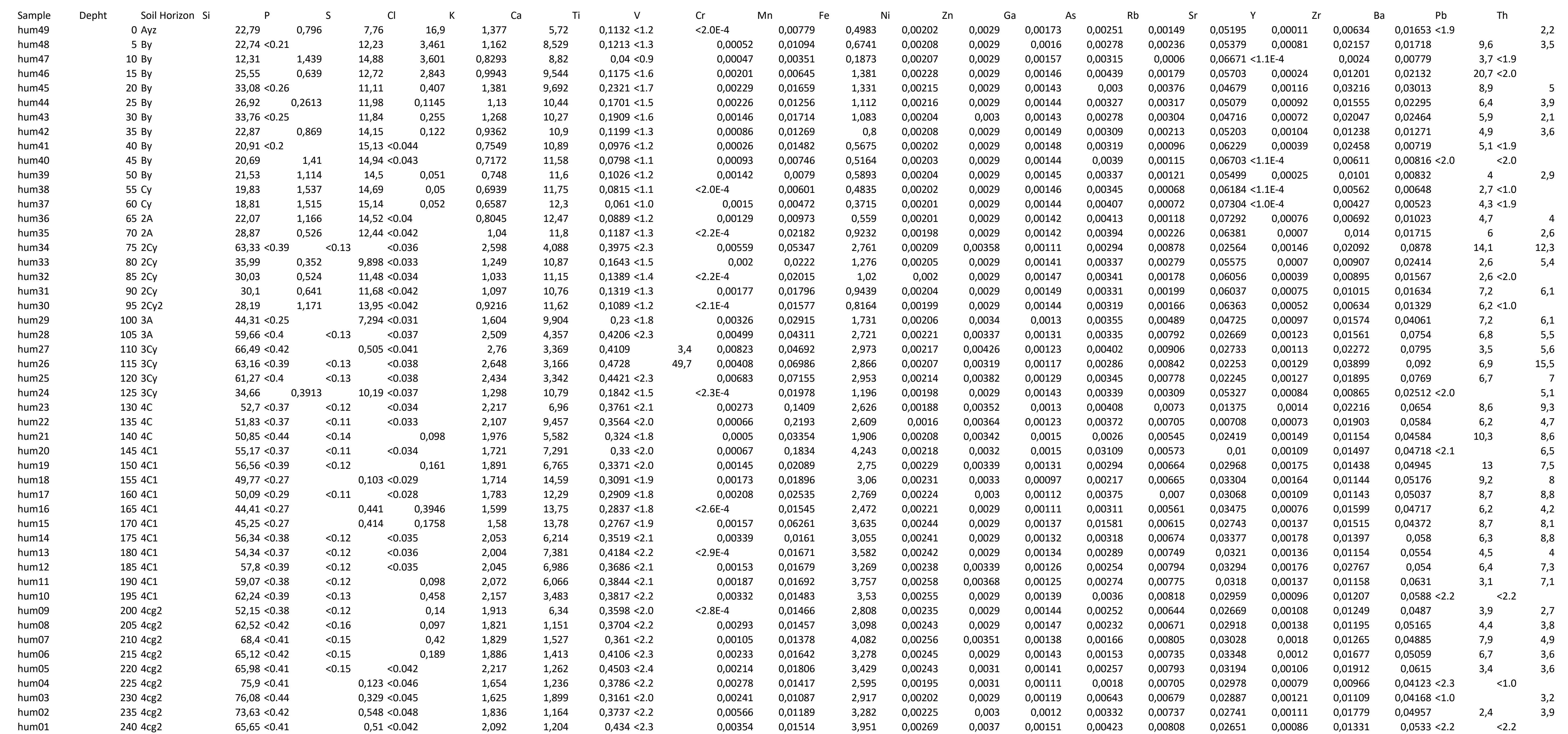




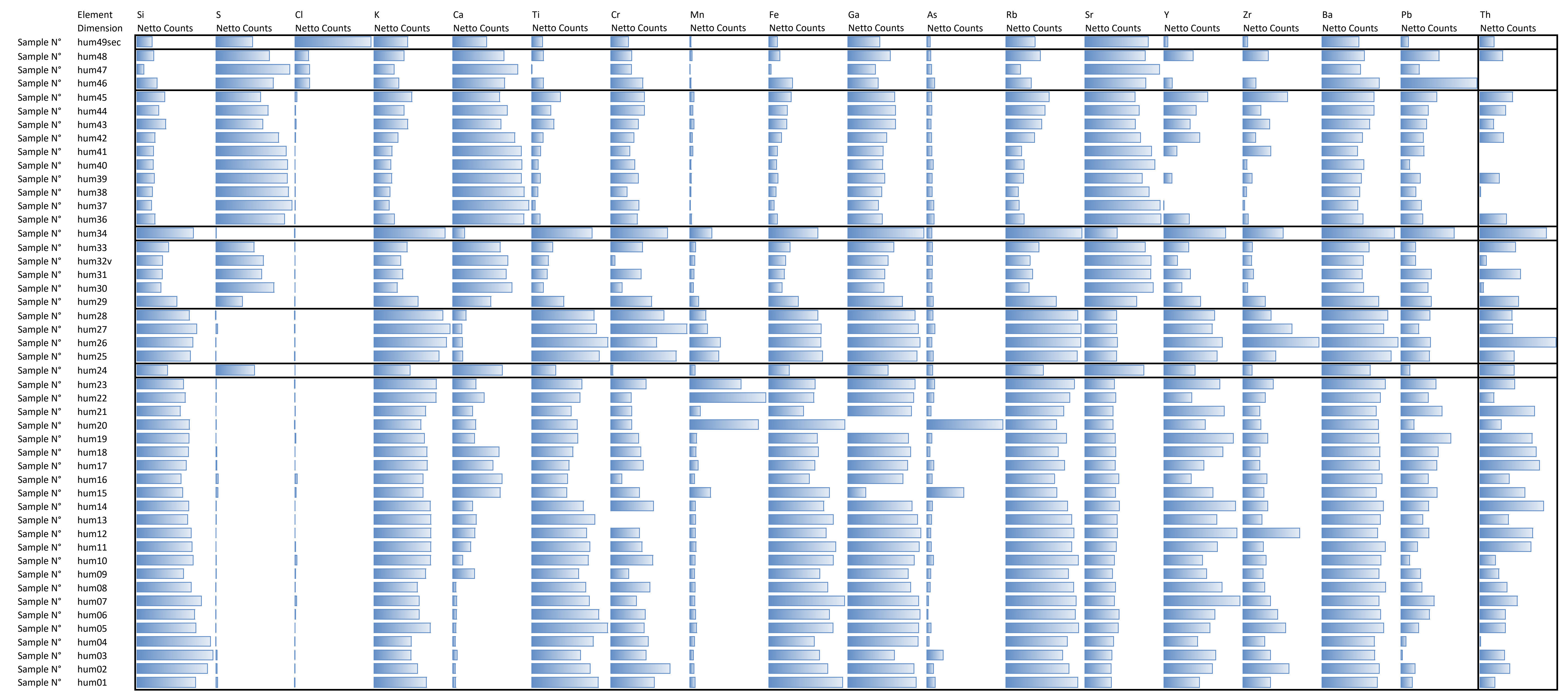

